\title{
Life strategy, ecophysiology and ecology of seaweeds in polar waters
}

\author{
C. Wiencke - M. N. Clayton · I. Gómez • \\ K. Iken · U. H. Lüder · C. D. Amsler · \\ U. Karsten · D. Hanelt $\cdot$ K. Bischof $\cdot$ K. Dunton
}

Received: 7 March 2006/ Accepted: 8 May 2006

(C) Springer Science+Business Media B.V. 2006

\begin{abstract}
Polar seaweeds are strongly adapted to the low temperatures of their environment, Antarctic species more strongly than Arctic species due to the longer cold water history of the Antarctic region. By reason of the strong isolation of the Southern Ocean the Antarctic marine flora is characterized by a high degree of endemism, whereas in the Arctic only few endemic species have been found so far. All polar species are strongly shade adapted and their phenology is finely tuned to the strong seasonal changes of the light conditions. The paper summarises the
\end{abstract}

C. Wiencke $(\bowtie) \cdot$ U. H. Lüder

Alfred Wegener Institute for Polar and Marine

Research, Am Handelshafen 12, D-27570

Bremerhaven, Germany

e-mail: cwiencke@awi-bremerhaven.de

\section{N. Clayton}

School of Biological Sciences, Monash University,

P.O Box 18, Melbourne, Victoria 3800, Australia

\section{Gómez}

Instituto de Biología Marina, Universidad Austral de Chile, Casilla 567, Valdivia, Chile

K. Iken

Institute of Marine Science, University of Alaska

Fairbanks, O’Neill Bldg., Fairbanks, AK 99775, USA

C. D. Amsler

Department of Biology, University of Alabama at

Birmingham, Birmingham, AL 35294-1170, USA present knowledge of seaweeds from both polar regions with regard to the following topics: the history of seaweed research in polar regions; the environment of seaweeds in polar waters; biodiversity, biogeographical relationships and vertical distribution of Arctic and Antarctic seaweeds; life histories and physiological thallus anatomy; temperature demands and geographical distribution; light demands and depth zonation; the effect of salinity, temperature and desiccation on supraand eulittoral seaweeds; seasonality of reproduction and the physiological characteristics of

\author{
U. Karsten \\ Institute of Biological Sciences, \\ Applied Ecology, University of Rostock, \\ Albert-Einstein-Strasse 3, D-18051 Rostock, \\ Germany \\ D. Hanelt \\ Biocenter Klein Flottbek, University \\ of Hamburg, Ohnhorst-Str. 18, D-22609 Hamburg, \\ Germany \\ K. Bischof \\ Institute for Polar Ecology, University \\ of Kiel, Wischhofstr. 1-3, D-24148 Kiel, \\ Germany \\ K. Dunton \\ Marine Science Institute, University of Texas at \\ Austin, 750 Channel View Drive, Port Aransas, \\ TX 78373, USA
}


microscopic developmental stages; seasonal growth and photosynthesis; elemental and nutritional contents and chemical and physical defences against herbivory. We present evidence to show that specific characteristics and adaptations in polar seaweeds help to explain their ecological success under environmentally extreme conditions. In conclusion, as a perspective and guide for future research we draw attention to many remaining gaps in knowledge.

Keywords Chemical ecology $\cdot$ Freezing · Growth · Light $\cdot$ Phenology $\cdot$ Photosynthesis · Polar algae $\cdot$ Salinity $\cdot$ Seaweeds $\cdot$ Temperature

\section{History of seaweed research in the polar regions}

The first phycological studies in the Arctic and the Antarctic regions took place in the first half of the 19th century. Studies on Antarctic seaweeds started in 1817 with the work of Gaudichaud, Bory, Montagne, Hooker and Harvey (Godley 1965). Later, between 1882 and 1909, intensive studies were carried out by Skottsberg, Reinsch, Gain, Hariot, Kylin, Hylmö, Foslie and others (Papenfuss 1964). After this period of mostly taxonomic and biogeographical investigations, which culminated in the publication of the catalogue by Papenfuss (1964), numerous diving investigations were conducted in West Antarctica by, among others, Neushul (1965), Délépine et al. (1966), Lamb and Zimmermann (1977), Moe and DeLaca (1976), Richardson (1979), Klöser et al. (1996) and in East Antarctica by Zaneveld (1968) and Cormaci et al. (1997). These studies gave greater insight into the depth distribution of Antarctic seaweeds and allowed more detailed studies on the life histories, ecophysiology and ecology of seaweeds from Antarctica. The highly fragmented information on the seaweeds of Antarctica was summarized recently in a synopsis by Wiencke and Clayton (2002).

Early algal research in the Arctic started in 1849 in the Canadian Arctic with Harvey and Dickie (Lee 1980). The Russian phycologist Kjellman worked in many places in the Arctic, especially in the Russian Arctic, the northern Bering Sea and Spitsbergen. His book "The algae of the Arctic Sea" (Kjellman 1883) is a taxonomic and biogeographic baseline study. Detailed studies on seaweeds from Greenland were made by Rosenvinge (1898), and in the 20th century by Lund (1951, 1959a, b) and Pedersen (1976). Taxonomic information concerning seaweeds from Spitsbergen and the Russian Arctic is also available in publications by Svendsen (1959), Zinova (1953; 1955), Vinogradova (1995) and many others. A very valuable contribution on seaweeds from the north-eastern coast of North America is the book by Taylor (1966; first published 1937). The first extensive diving studies were performed by Wilce (1963), Chapman and Lindley (1980) and by Dunton et al. (1982) in the Canadian and Alaskan Arctic. As in Antarctica, diving is an essential prerequisite for detailed studies on all aspects of seaweed biology and this technique has since been widely applied in several regions of the Arctic. Since 1991 there has been intensive research on the ecology and ecophysiology of Arctic seaweeds on Spitsbergen (Hop et al. 2002; Wiencke 2004).

\section{The environment of seaweeds in polar waters}

The polar regions are characterized by pronounced seasonal variations of the light regime, low temperatures, and long periods of snow and ice cover. Littoral seaweed communities are often strongly impacted by icebergs and sea ice especially in areas with high wave action (Klöser et al. 1994). Icebergs can run aground in the Antarctic down to $600 \mathrm{~m}$ depth (Gutt 2001). First-year sea ice has a thickness of up to $2 \mathrm{~m}$, and in the Arctic multi-year ice can reach depths of about $40 \mathrm{~m}$ (Gutt 2001). Anchor ice forms on the seabed in shallow waters and can enclose seaweeds especially in East Antarctica (Miller and Pearse 1991).

The seasons in the sublittoral are characterized in polar regions by short periods of favourable light conditions and extended periods of darkness due to the polar night and sea ice cover in winter (Kirst and Wiencke 1995). At the poleward distribution limits of seaweeds, at $77^{\circ} \mathrm{S}$ and $80^{\circ} \mathrm{N}$, respectively, the annual solar radiation is $30-50 \%$ less than in temperate to tropical regions, and the polar night lasts for about 4 months 
(Lüning 1990). At lower latitudes, e.g. close to the northern limit of the Antarctic region, in the South Shetland Islands, daylength varies between $5 \mathrm{~h}$ in winter and $20 \mathrm{~h}$ in summer (Wiencke 1990a). This extreme light regime has strong implications for primary productivity in general and for the seasonal development of seaweeds. In addition the long periods of darkness are further extended due to the formation of sea ice. If the ice is also covered by snow, irradiance can be diminished to less than $2 \%$ of the surface value. Consequently, seaweeds may be exposed up to about 10 months of darkness or very low light conditions (Chapman and Lindley 1980; Dunton 1990; Miller and Pearse 1991; Drew and Hastings 1992; Klöser et al. 1993).

After sea ice break-up in spring, light penetrates deeply into the clear water. On King George Island (South Shetland Islands) at this time average photon fluence rates are $70 \mu \mathrm{mol}$ $\mathrm{m}^{-2} \mathrm{~s}^{-1}$ at midday in $30 \mathrm{~m}$ depth (Gómez et al. 1997). On Signy Island (South Orkney Islands) the euphotic zone, i.e. the $1 \%$ depth for photosynthetically active radiation (PAR), was determined at $29 \mathrm{~m}$ (Brouwer 1996). UV-radiation (UVR) and blue light are, however, more strongly attenuated. The $1 \%$ depth for UVB radiation, representing more or less the threshold irradiance of UV-B with the potential to affect primary plant productivity negatively, is located between 4 and $8 \mathrm{~m}$ on Spitsbergen (Hanelt et al. 2001; van de Poll et al. 2002). Later, in summer, coastal waters in polar regions become more turbid due to the development of phytoplankton blooms and the inflow of melt water carrying fine sediments and detritus that strongly affect light transmission. With increasing turbidity the wavelengths shift from the blue to the green waveband in deep waters (Jerlov 1976). Consequently, sublittoral seaweeds are exposed only to low irradiances even though the sun altitude is relatively high (e.g. about $34^{\circ}$ elevation in July compared to only $14^{\circ}$ in April at $79^{\circ}$ North at noon).

In a canopy of kelps or other overstory brown algae, PAR is strongly attenuated, and understorey species are exposed to even lower irradiances (Hanelt et al. 2003). The light quality also changes. Below the canopy the spectrum is enriched in green and in far red light, probably affecting photosyn- thesis as well as the photomorphogenetic development of the understorey (Salles et al. 1996).

The possible impact of enhanced UVB radiation due to stratospheric ozone depletion on primary production of seaweeds is higher during the spring season, as organisms in the eulittoral and upper sublittoral zone are already affected by UVB radiation throughout the polar day and turbid melt water input occurs only during the summer season. The strong increase of turbidity due to a discharge of sediments by melt water and glaciers applies especially to Arctic shorelines in halfopen fjord systems where the water exchange with the clearer oceanic water is retarded (Svendsen et al. 2002). On open coastlines the melt water is exchanged much faster with clear oceanic water so that seaweeds are exposed to biologically effective UVR for longer time periods.

The inflow of melt water in summer has considerable effects on the salinity and temperature regime in inshore waters. During times of calm weather, there is a strong stratification in the water body with a layer of fresh water above a layer of denser sea water. However, due to vertical water mixing by wave action and wind the deeper water zones also become affected and a salinity decrease may occur down to about $20 \mathrm{~m}$ depth (Hanelt et al. 2001).

In contrast to the strong seasonal variation in the radiation conditions, water temperatures in the sublittoral mostly change only little between $1.8^{\circ} \mathrm{C}$ in winter and $+2.0^{\circ} \mathrm{C}$ in summer, e.g. in the Antarctic Peninsula region (Drew and Hastings 1992; Klöser et al. 1993). At the boundary with the temperate region, maximum summer temperatures can go up to about $5^{\circ} \mathrm{C}$ in the Antarctic and up to about $8-10^{\circ} \mathrm{C}$ in the Arctic (Wiencke and tom Dieck 1989; Lüning 1990; Svendsen et al. 2002).

Macronutrient concentrations are high and not limiting for seaweeds at any time of the year in the Antarctic (Deacon 1937; Drew and Hastings 1992). However, iron concentrations are low in the Antarctic and inhibit phytoplankton growth (de Baar 1994; de Baar et al. 1995). Whether iron deficiency also affects seaweeds is unclear. High macronutrient concentrations are also present in the area of Spitsbergen, which obtains nutrientrich water from the south during parts of the year (the so-called Spitsbergen current). This is one 
reason why the seas of the European Arctic belong to the most productive seas in the world (Orheim et al. 1995). In general, there is a considerable seasonal fluctuation of macronutrients. Nitrogen and phosphorus levels are relatively high during the winter months but both macronutrients are almost fully depleted in summer (Chapman and Lindley 1980). This applies also to the area close to Spitsbergen (Aguilera et al. 2002).

The tidal amplitudes on King George Island and on Spitsbergen vary between 120 and $150 \mathrm{~cm}$ (Schöne et al. 1998; Svendsen et al. 2002). Like terrestrial vegetation, supra-and eulittoral seaweeds are exposed to strongly changing light conditions and temperatures, but also frequently to desiccation and low or high salinities due to the tidal regime and the weather. Photon fluence rates close to terrestrial cryptogams in the maritime Antarctic vary between $0.1 \mathrm{~mol} \mathrm{~m}^{-2} \mathrm{~d}^{-1}$ in winter and more than $30 \mathrm{~mol} \mathrm{~m}^{-2} \mathrm{~d}^{-1}$ with maxima around $1600 \mu \mathrm{mol} \mathrm{m}^{-2} \mathrm{~s}^{-1}$ in summer (Schroeter et al. 1995; Winkler et al. 2000). The annual variation of thallus temperatures of a lichen growing on a coastal rock on King George Island (Antarctica) was between $+27.4^{\circ} \mathrm{C}$ in summer and $-27.3^{\circ} \mathrm{C}$ in winter (Schroeter et al. 1995). However, smaller annual amplitudes of only $10^{\circ} \mathrm{C}$ also occur depending on the degree of exposure and snow cover (Winkler et al. 2000).

With increasing temperature in spring the supralittoral is flushed by meltwater, followed by a period of desiccation in summer, which can be interrupted by rehydration during rain-or snowfall (Davey 1989; Schroeter et al. 1995) or during high tides. Salinity changes strongly in the supralittoral due to the effects of tides, salt spray, desiccation, overflow with melt water and precipitation. In the eulittoral salinity rises are less strong and less frequent than in the supralittoral. On the other hand, low salinities are quite common during low tides, precipitation and meltwater discharge. Klöser (1994) determined salinities between 27 and 41 PSU in the eulittoral on King George Island. At low tide temperatures in tide pools may rise far above the coastal water temperatures up to almost $14^{\circ} \mathrm{C}$ in summer (Klöser 1994; Moore et al. 1995). Winter temperatures may be very low and depend, apart from the air temperatures, on the thickness of the ice cover in winter.

Despite the remoteness of the polar regions pollution is an issue both in the Arctic and the Antarctic. For example, radionuclide contaminants such as Technetium-99 $\left({ }^{99} \mathrm{Tc}\right)$ are present around the Arctic archipelago of Svalbard through the long-range oceanic transport of discharges of radioactive effluents from nuclear reprocessing plants in Europe and global fallout (Gerland et al. 2003; Gwynn et al. 2004). Another problem are oil spills. When the Argentinean ship Bahia Paraiso ran aground near Anvers Island at the Antarctic Peninsula more than 150,000 gallons of petroleum were released to the surrounding bays (Kennicutt II et al. 1990). Such oil spills can potentially cause servere harm depending on the amount and type of material released.

\section{Biodiversity, biogeographical relationships and vertical distribution of Arctic and Antarctic seaweeds}

The Arctic and the Antarctic Oceans differ considerably with respect to their genesis and their cold water history. The Southern Ocean has had no land bridge to temperate regions since the late Mesozoic and has been further separated from the neighbouring southern continents by the Antarctic Circumpolar Current since $26 \mathrm{Ma}$ (Hempel 1987; Lüning 1990; Kirst and Wiencke 1995). During the first major glaciation in East Antarctica $14 \mathrm{Ma}$ ago water temperatures decreased and they have been low in the Southern Ocean since then (Crame 1993). In contrast, the broad shelf areas of the Arctic Ocean have had a continuous connection to the temperate coasts of America and Eurasia, and a perennial ice cover did not develop before 0.7-2.0 Ma ago (Clarke 1990). These distinctions are the major reasons for the differences in seaweed biodiversity of both polar regions.

The strong isolation of the benthic seaweed flora of the Southern Ocean has resulted in a high degree of endemism in Antarctica. 33\% of all seaweed species are endemic to the Antarctic region. Within the Heterokontophyta $44 \%$ of the 
species are endemic, within the Rhodophyta $32 \%$ and within the Chlorophyta $18 \%$ (Wiencke and Clayton 2002). There is one endemic order, the kelp-like brown algal order Ascoseirales, and there are several endemic genera: among the brown algae, Himantothallus, Cystosphaera and Phaeurus, among the red algae Gainia, Notophycus and Antarcticothamnion, and among the green algae Lambia and Lola (Wiencke and Clayton 2002). Well-known Antarctic endemic species include the brown algae Himantothallus grandifolius, Cystosphaera jacquinotii, the red alga Porphyra endiviifolium and the green alga Lambia antarctica. The Antarctic region is the only region in the world devoid of kelps, brown algae of the order Laminariales (Moe and Silva 1977). This order is ecologically replaced by the Desmarestiales. According to phylogenetic and morphological analyses and studies on ecophysiological traits this order is considered to have originated in the Southern Ocean and subsequently radiated into the Northern Hemisphere (Peters et al. 1997). A conspicuous character of the Antarctic seaweed flora is the scarcity of small macroalgal epiphytes compared to temperate regions. In fact, these epiphytes are not absent, they rather occur as endophytes inside larger seaweeds, well protected against herbivory by mesograzers (Peters 2003). This suggests that mesoherbivory can be quite intense in Antarctica.

In contrast to the strong endemism in Antarctic macroalgae only very few endemic Arctic species have been found so far. About half a dozen species are restricted to the Arctic including the brown algae Punctaria glacialis, Platysiphon verticillatus and the red alga Petrocelis polygyna (Wilce 1990). Most species have a distribution that extends well into the temperate region, e.g. the kelp Laminaria solidungula and the red algae Devaleraea ramentacea, Turnerella pennyi, Neodilsea integra and Pantoneura baerii (Lüning 1990).

Compared to rich seaweed floras like those in temperate southern Australia with about 1155 species (Womersley 1991), low species richness is characteristic for both polar seaweed floras. In the Antarctic, 119 species have been recorded so far (Wiencke and Clayton 2002) and in the Arctic there are about 150 species (Wilce 1994). These numbers are, however, likely to be underesti- mated due to the infrequency of scientific collections, the extreme remoteness and logistic difficulties. In Antarctica most species occur in the Antarctic Peninsula region and only very few species are recorded at the southernmost distribution limit in the Ross Sea. A similar decrease in species richness has been detected in East Greenland between Scoresby Sound, Franz Josephs Fjord and Jörgen Brönlunds Fjord (70, 74 and $82^{\circ} \mathrm{N}$, respectively; Lund 1951, 1959a, b). On the panarctic level, macroalgal species richness seems to dramatically decrease from the western (Atlantic) sector to the eastern (Pacific) sector. While about 70 species have been recorded from the Svalbard region (Weslawski et al. 1993, 1997; Vinogradova 1995), only about 10 species are known from the rocky littoral regions in the Alaskan Beaufort Sea (Dunton and Schonberg 2000).

As a result of the strong effect of the Antarctic Circumpolar Current on the dispersal of seaweed propagules (Lüning 1990) many non-endemic species of the Antarctic seaweed flora have a circumpolar distribution. Among the species also occurring on sub-Antarctic islands and Tierra del Fuego are the red alga Iridaea cordata, the brown alga Geminocarpus geminatus and the green alga Monostroma hariotii. Some species, e.g. the red alga Ballia callitricha and the brown alga Adenocystis utricularis, even occur in New Zealand and Australia. A similar connection between the Antarctic and the cold temperate region of South America has also been recorded for marine invertebrates (Clarke et al. 2005). At least 20 algal species from the Antarctic are cosmopolitan, e.g. the red alga Plocamium cartilagineum, the brown alga Petalonia fascia and the green alga Ulothrix flacca (Papenfuss 1964; Wiencke and Clayton 2002). It is possible that some such species may be recent invaders from temperate regions (Clayton et al. 1997).

A few seaweed species have a disjunct amphiequatorial distribution and occur both in the Antarctic and the Arctic, e. g. Acrosiphonia arcta and Desmarestia viridis/confervoides. Molecular studies indicate that the biogeographic disjunctions of these species are recent and probably date back to the maximum of the Würm/Wisconsin glaciation 18,00 years ago (van 
Oppen et al. 1993). The units of dispersal were certainly the microscopic stages in the life cycle because they are more resistant to high temperatures allowing the possibility of a passage through the tropics during times of lowered water temperatures (Peters and Breeman 1992; Wiencke et al. 1994; Bischoff and Wiencke 1995a).

Apart from the few species endemic to the Arctic and various cosmopolitan species such as the red alga Audouinella purpurea, the brown alga Scytosiphon lomentaria and the green alga Blidingia minima, the Arctic seaweed flora has affinities to the Atlantic, the Pacific and the Indo-Pacific region (Wilce 1990). An example of an invader from the Pacific may be Acrosiphonia arcta. Populations of this species from the Arctic and the North Atlantic seem to originate from the Pacific according to molecular studies (van Oppen et al. 1994). But over $90 \%$ of the species in the Arctic originate from Atlantic populations (Dunton 1992). This is particularly obvious in regions with strong influx of Atlantic waters, e.g. in Svalbard (Svendsen et al. 2002, Hop et al. 2002). However, even in the coastal areas of the Beaufort Sea there is a strong Atlantic influence, marked by the kelps Laminaria solidungula and Alaria esculenta (Dunton 1992) while the Canadian Arctic also has a high proportion of macroalgae of Pacific origin (Cross et al. 1987).

In both polar regions seaweeds are almost entirely subtidal. However, there are some specialized species with a bipolar distribution that occur exclusively in the supralittoral, i.e. in the spray zone. These are the green alga Prasiola crispa, which also grows more inland close to seabird rockeries under conditions of low $\mathrm{pH}$ and high nutrient concentrations (Knebel 1936) and the red alga Bangia atropurpurea (Bird and Mc Lachlan 1992; Clayton et al. 1997). The green alga Urospora penicilliformis and species of the genus Ulothrix grow just around the high tide level both in the Antarctic and the Arctic. Acrosiphonia arcta is a species typical for the lower eulittoral in both polar regions.

A conspicuous species in the upper eulittoral in the Antarctic is the red alga Porphyra endiviifolium and in the lower eulittoral/upper sublittoral the green alga Enteromorpha bulbosa and the brown alga Adenocystis utricularis are common (Westermeier et al. 1992; Wiencke and Clayton 2002). Tide pools and crevices in the lower sublittoral are often colonized by upper sublittoral species such as the red algae Palmaria decipiens and Iridaea cordata. The upper 5-15 m of the sublittoral are exposed to ice floes and are often devoid of large, perennial algae. Only crustose species or developmental stages can persist here. Below this zone, large brown algae dominate the sublittoral in West Antarctica: Ascoseira mirabilis and Desmarestia menziesii occur in the upper sublittoral, D. anceps in the mid sublittoral and Himantothallus grandifolius grows in the lower sublittoral (DeLaca and Lipps 1976; Lamb and Zimmermann 1977; Amsler et al. 1995; Klöser et al. 1996; Quartino et al. 2001, 2005). At higher latitudes in East Antarctica only few species occur, in particular Palmaria decipiens, Phyllophora antarctica and I. cordata (Zaneveld 1968; Miller and Pearse 1991; Cormaci et al. 1992).

In the Arctic the barren zone heavily exposed to floating ice extends down to about $2 \mathrm{~m}$ water depth. The upper sublittoral on Spitsbergen is characterized by the brown algae Fucus distichus, Pylaiella littoralis, Chordaria flagelliformis, the kelp Saccorhiza dermatodea, the red alga Devaleraea ramentacea and green algae of the genus Acrosiphonia. The zone below is dominated by the kelps Alaria esculenta, Laminaria digitata and L. saccharina. Characteristic for the lower sublittoral are the red algae Phycodrys rubens and Ptilota gunneri. The Arctic kelp, L. solidungula, occurs in this zone as well but only in the inner part of the fjords (Svendsen 1959; Hop et al. 2002; Wiencke et al. 2004). The seaweed vegetation in the Canadian Arctic (Baffin Island) is similar to that in Spitsbergen with a shallow $F$. distichus zone, the upper sublittoral characterized by Stictyosiphon tortilis, P. littoralis and Dictyosiphon foeniculaceus (Cross et al. 1987). Deeper communities are dominated by the kelps L. saccharina, L. solidungula, A. esculenta and Agarum cribrosum, interspersed with the red algae Dilsea integra, D. ramentacea and Rhodomela confervoides. In contrast, no supralittoral or intertidal algae have been recorded from the Alaskan Beaufort Sea. Here, algae are restricted to scattered rocky habitats in shallow waters (about 
5-10 m), which are protected by barrier islands from iceberg scouring. Laminaria solidungula is the dominant kelp species, although Alaria esculenta and $L$. saccharina can also be found regularly (Dunton and Schonberg 2000). Characteristic red algal species are Phycodrys rubens, Odonthalia dentata, Dilsea integra, Phyllophora truncata and Rhodomela subfusca. Exposed rock is usually covered by encrusting coralline red algae, Lithothamnion spp. (Konar and Iken 2005).

\section{Reproductive and physiological thallus anatomy}

The enigma of reproduction and life histories of endemic Antarctic Desmarestiales and of Ascoseira mirabilis has been clarified. The sorus structure of H. grandifolius (Moe and Silva 1981; Wiencke and Clayton 1990), D. anceps (Moe and Silva 1981; Wiencke et al. 1996) and D. antarctica (Moe and Silva 1989; Wiencke et al. 1991) is similar, indicating an evolutionary relationship. Unilocular sporangia are cylindrical, borne terminally on 2-4 celled stalks and are interspersed with paraphyses composed of $2-4$ cells with many physodes. With respect to sorus morphology, $D$. menziesii exhibits a closer similarity to the Arctic cold-temperate species D. aculeata (Wiencke et al. 1995), whereas Phaeurus antarcticus resembles the North Atlantic-Mediterranean species Arthrocladia villosa (Clayton and Wiencke 1990). In P. antarcticus, sporangia are catenate and develop in rows in adjacent cells as filamentous outgrowths of the cortex, interspersed with club-shaped sterile hairs. These phylogenetic relationships have been confirmed meanwhile by molecular data (Peters et al. 1997). Ascoseira mirabilis, whose exact phylogenetic relationships are still unresolved, has a fucalean type of life history (Clayton 1987). There is one free-living diploid generation with conceptacles scattered over both surfaces. These contain densely packed chains of gametangia that release biflagellate isomorphic gametes. Zygotes develop into new individuals.

A striking feature of several Antarctic Desmarestiales and A. mirabilis is their anatomical complexity resembling that of Laminaria species from the northern Hemisphere. As far as we know today these taxa are characterized by a highly diversified structure and complex morphofunctional processes including a temporal synchronization between photosynthesis and growth as well as the long-distance transport of organic substances (Lüning et al. 1973; Schmitz 1981; Clayton and Ashburner 1990; Drew and Hastings 1992; Gómez et al. 1996). Such characteristics represent strategies to cope with the marked seasonality in polar and cold-temperate regions (Chapman and Lindley 1980; Gómez and Wiencke 1998; Gómez and Lüning 2001).

As in other species of Laminaria the blade of L. solidungula has a basally located meristem, which is active only in winter and forms-comparable with L. hyperborea-a new blade at the distal end (Taylor 1966; Dunton and Jodwalis 1988). Up to three generations of blades may be found in one individual. As in species of Laminaria, blades of Himantothallus grandifolius grow in their lower part (Dieckmann et al. 1985; Drew and Hastings 1992). Punch-hole experiments with A. mirabilis indicate that the blade elongates longitudinally as in Laminaria solidungula through a seasonally active intercalary meristem (Gómez et al. 1995a).

Carbon fixation rates in kelps and kelp-like brown algae differ between blade parts (Arnold and Manley 1985; Gómez et al. 1995a, b; CabelloPasini and Alberte 2001). During the growth phase in late winter-spring, net photosynthetic rates (net $\mathrm{P}_{\max }$ ) in $A$. mirabilis are slightly higher in the middle region compared to the basal and distal regions (Gómez et al. 1995a). In comparison, in L. solidungula, C-fixation rates are lowest in meristematic tissue, highest in first year tissue and intermediate in second-blade tissue (Dunton and Jodwalis 1988). This pattern is related to the ontogeny within the blade, i.e. photosynthetic activity increases with age of the tissues reaching a maximum but then decreases with further aging. In apical regions, erosion and senescence take place.

Over the years, the blade in Ascoseira becomes thicker and more complex as new tissue is formed each growth season, resulting in modifications not only of the photosynthetic gradients but also of the photosynthetic capacity and efficiency along the thallus. Two age-components must be 
considered here: The age of the different blade tissues and the age of the whole plant. In this context, 2-year old plants of Ascoseira are characterized by net $\mathrm{P}_{\max }$ and $\alpha$-values almost twice that of 3-year old individuals. However, other parameters such as dark respiration, saturation $\left(\mathrm{E}_{\mathrm{k}}\right)$ and compensation $\left(\mathrm{E}_{\mathrm{c}}\right)$ points do not show obvious differences (Gómez et al. 1996). The photosynthetic variability correlated with tissue age may also be seen in terms of the development of the photosynthetic apparatus with ontogeny. In both age classes, middle regions have a higher net $\mathrm{P}_{\max }$ than basal and distal regions, suggesting that photosynthesis is low due to the presence of a non-developed photosynthetic apparatus in the basal region, and decreases in the oldest distal tissues due to senescence processes. Similar results were obtained in young and adult plants of L. solidungula (Dunton and Jodwalis 1988).

Küppers and Kremer (1978) associated the increased ${ }^{14} \mathrm{C}$-assmilation in the middle and distal regions of Laminaria species with a higher activity of the Calvin cycle enzyme ribulose 1,5-bisphosphate carboxylase-oxygenase (RUBISCO). Moreover, these authors demonstrated longitudinal profiles in light independent $\mathrm{C}$-fixation in these species coupled to a high activity of the enzyme phosphoenolpyruvate carboxykinase (PEP-CK) in the meristematic region ( $\beta$-carboxylation). The activities of these carboxylating enzymes apparently respond to the growth characteristics of Laminaria. In fact, Laminaria species from cold-temperate and Arctic regions grow in winter or in dim light and it is likely that such an alternative carboxylating mechanism is advantageous for these species (Küppers and Kremer 1978). $\beta$-carboxylation is also linked to the growth requirements of these algae. For example, light-independent carbon fixation provides C-skeletons (preferentially amino-acids) for both biosynthesis and anabolic processes, thus replenishing some carbon intermediates in e.g. the Krebs cycle (Kremer 1981b; Falkowski and Raven 1997). Particularly, in the meristematic region of Laminaria, PEP-CK uses $\mathrm{CO}_{2}$ lost in glycolysis of mannitol translocated from the distal region to the meristem (Kremer 1981a; Kerby and Evans 1983).
The patterns of C-fixation in Ascoseira exhibit also intra-blade variations (Gómez et al. 1995a) although some differences with respect to patterns reported in Laminaria are observed. Both light dependent and light independent $\mathrm{C}$-fixation increase with tissue age reaching a maximum in the middle/distal parts of the blade. In contrast, members of the Laminariales studied to date show highest rates of light dependent carbon fixation in distal and highest light independent $\mathrm{C}$ fixation in the basal parts (Küppers and Kremer 1978). The different thallus allocation of light independent $\mathrm{C}$ fixation in $A$. mirabilis may be related to the high dark respiration rates observed in distal blade regions (Gómez et al. 1995a, 1996). It is not clear, however, whether light independent C-fixation may compensate for $\mathrm{C}$ losses due to respiration as reported by Kremer (1981b). Thomas and Wiencke (1991) could not conclusively demonstrate a relationship between light independent $\mathrm{C}$-fixation and dark respiration in Antarctic marine algae. In general, dark C-fixation varied between $4.9 \%$ and $31 \%$ of dark respiration in five brown algae and one red alga. In species such as $H$. grandifolius and $D$. anceps, low dark $\mathrm{C}$-assimilation rates were coupled to high respiration rates as in Ascophyllum nodosum indicating a net $\mathrm{C}$ loss due to respiration in the dark (Johnston and Raven 1986).

In kelps sugars are synthesized and stored as polysaccharides (e.g. laminaran) in the middle and distal assimilatory tissues of the algae, from which they are then translocated as low-molecular-weight compounds (e.g. mannitol) in trumpet hyphae to the growth region (Kremer 1981a, b). The trumpet hyphae of Laminariales are elongated, longitudinally oriented cells in the medulla with trumpet like ends. The cross walls are perforated by numerous pits resembling the sieve plates of sieve tubes in higher plants (Schmitz 1981, 1990; Buggeln 1983). Similar trumpet hyphae are present in the medulla of $H$. grandifolius (Moe and Silva 1981) and in the other Desmarestiales Phaeurus antarcticus (Clayton and Wiencke 1990), Desmarestia antarctica (Moe and Silva 1989; Wiencke et al. 1991) and D. menziesii (Scrosati 1992; Wiencke et al. 1995). The trumpet hyphae can be interconnected by sieve plates and are always surrounded by numerous small cells 
that probably function as transfer cells. In A. mirabilis longitudinally arranged "conducting channels" comparable to the trumpet cells found in Laminariales are present in the medulla (Clayton and Ashburner 1990). The channels are aseptate, multinucleate structures with ensheathing filaments often interconnected through sievelike wall perforations. Although no conclusive evidence for a possible transport function of the conducting channels in A. mirabilis is available, differential allocation of reserve carbohydrates associated to meristem activity strongly suggest the involvement of these structures in long distance transport (Gómez and Wiencke 1998).

Overall, the findings that photosynthesis and carbon allocation vary as a function of blade development add new evidence to a convergent morpho-functional evolution between large Antarctic brown algae and Laminariales of the northern Hemisphere. In this case not only morphological organization, but also the metabolic differentiation along the blade, are common characteristics of the taxa. Such characteristics certainly reflect adaptive mechanisms to withstand resource limitation in seasonally changing environments, which have ultimately led to the ecological success of these algae in polar regions.

\section{Temperature demands and geographical distribution}

Photosynthesis of polar seaweeds shows a considerable adaptation to the low temperatures of the environment. Maximum photosynthetic rates of endemic Antarctic species are at a temperature of $0^{\circ} \mathrm{C}$ similar to values from temperate species measured at higher temperatures (Drew 1977; Thomas and Wiencke 1991; Wiencke et al. 1993; Weykam et al. 1996; Eggert and Wiencke 2000). Moreover, the temperature optima for photosynthesis at least in some species from the Antarctic are well below values determined in temperate species. The lowest temperature optima have been determined in the brown algae Ascoseira mirabilis $\left(1-10^{\circ} \mathrm{C}\right)$ and Himantothallus grandifolius (10-15² C; Drew 1977; Wiencke et al. 1993). The red algae Ballia callitricha and Gigartina skottsbergii also exhibit values between 10 and $15^{\circ} \mathrm{C}$, whereas Kallymenia antarctica, Gymnogongrus antarcticus and Phyllophora ahnfeltioides exhibit broad optima between 10 and 20 (to 25$)^{\circ} \mathrm{C}$ (Eggert and Wiencke 2000). Studies on the few Arctic seaweeds show a temperature optimum at $20^{\circ} \mathrm{C}$ (Healey 1972). For comparison, in cold-and warm-temperate species optimum values of $20-25^{\circ} \mathrm{C}$ and $25-35^{\circ} \mathrm{C}$ were determined, respectively (Lüning 1990). The temperature optima for respiration are clearly above the optima for photosynthesis but temperatures higher than $30^{\circ} \mathrm{C}$ have never been tested in Antarctic seaweeds (Drew 1977; Wiencke et al. 1993; Eggert and Wiencke 2000). Photosynthesis:respiration ratios are highest at the lowest tested temperature, $0^{\circ} \mathrm{C}$, and decrease with increasing temperatures due to different Q10 values for photosynthesis (1.4-3.5) and respiration (2.5-5.1).

The high P:R ratios at low temperatures are the major reason for the high growth rates of Antarctic species at low temperatures. In particular red and brown algal species from both polar regions exhibit temperature growth optima at $0-5^{\circ} \mathrm{C}$ or even at $-2^{\circ} \mathrm{C}$ (Wiencke and tom Dieck 1989, 1990; Novaczek et al. 1990; Bischoff and Wiencke 1993; Bischoff-Bäsmann and Wiencke 1996; Eggert and Wiencke 2000; McKamey and Amsler 2006). Some species like Georgiella confluens, Gigartina skottsbergii and Plocamium cartilagineum from the Antarctic grow only at $0^{\circ} \mathrm{C}$, the lowest temperature tested, but not at $5^{\circ} \mathrm{C}$ (Bischoff-Bäsmann and Wiencke 1996). The upper survival temperatures (USTs), determined after 2-week-exposures to different temperatures, are as low as $7-11^{\circ} \mathrm{C}$. Other Antarctic red algae grow up to $5^{\circ} \mathrm{C}$ or $10^{\circ} \mathrm{C}$ and have USTs of $\leq 19^{\circ} \mathrm{C}$ (Bischoff-Bäsmann and Wiencke 1996). The sporophytes of endemic Antarctic Desmarestiales grow up to $5^{\circ} \mathrm{C}$ and exhibit USTs of $11-13^{\circ} \mathrm{C}$. In contrast, their gametophytes grow up to $10^{\circ} \mathrm{C}$ or $15^{\circ} \mathrm{C}$ and have USTs between $15^{\circ} \mathrm{C}$ and $18^{\circ} \mathrm{C}$ (Wiencke and tom Dieck 1989, 1990). The upper limit for gametogenesis (ULG) in $D$. antarctica is $5^{\circ} \mathrm{C}$ (Wiencke et al. 1991). Antarctic cold-temperate species (especially from the eulittoral) have higher temperature requirements. They grow up to $10-15$ (or 20$)^{\circ} \mathrm{C}$ and show USTs between $13.5^{\circ} \mathrm{C}$ and $19^{\circ} \mathrm{C}$. Microthalli of Antarctic cold-temperate brown algae exhibit 
USTs between $21^{\circ} \mathrm{C}$ and $25^{\circ} \mathrm{C}$ and ULGs between $13^{\circ} \mathrm{C}$ and $15^{\circ} \mathrm{C}$ (Wiencke and tom Dieck 1990; Peters and Breeman 1993).

As far as we know today the temperature demands for growth of Arctic seaweeds are somewhat higher than endemic Antarctic species. It must, however, be pointed out that the temperature demands of truly endemic Arctic species (see chapter 3) have not been investigated so far. The sporophyte of the kelp Laminaria solidungula, whose distribution extends into the cold-temperate region as far as Newfoundland, grows at temperatures up to $15^{\circ} \mathrm{C}$ with an optimum at $5-10^{\circ} \mathrm{C}$ and USTs of $16^{\circ} \mathrm{C}$ (tom Dieck 1992). The male and female gametophytes of this species exhibit an UST of $18^{\circ} \mathrm{C}$ and lower survival temperatures (LSTs) of $\leq-1.5^{\circ} \mathrm{C}$ (Bolton and Lüning 1982; tom Dieck 1993). The red alga Devaleraea ramentacea, which is distributed from the Arctic to the cold temperate North Atlantic region, grows at up to $10^{\circ} \mathrm{C}$ with an optimum at $0^{\circ} \mathrm{C}$ and exhibits an UST of $18-20^{\circ} \mathrm{C}$ and an LST of $\leq-5^{\circ} \mathrm{C}$. The ULG of this species is $8^{\circ} \mathrm{C}$ (Novaczek et al. 1990; Bischoff and Wiencke 1993). Macrothalli of species with a prominent distribution in both, the Arctic and the cold-temperate region, grow at up to 15 or 20 (to 25$)^{\circ} \mathrm{C}$ with optima between 5 and 15 (to 20$)^{\circ} \mathrm{C}$ and exhibit USTs between 17 and 25 (to 26$)^{\circ} \mathrm{C}$. The LSTs are $\leq-1.5$ or $2^{\circ} \mathrm{C}$ (Wiencke et al. 1994). The microscopic gametophytes of Arctic cold-temperate Laminariales grow at up to $20^{\circ} \mathrm{C}$ and have USTs between 22 and 25 (to $28)^{\circ} \mathrm{C}$. Gametophytes of Alaria esculenta and Agarum cribrosum, however, exhibit USTs of 19$21^{\circ} \mathrm{C}$, as low as those of the more Arctic species Laminaria solidungula. The LSTs are either 0 , -1.5 or $-2^{\circ} \mathrm{C}$, the few data on ULGs vary between $10^{\circ} \mathrm{C}$ and $17^{\circ} \mathrm{C}$ (Wiencke et al. 1994).

The northern distribution of endemic Antarctic species is often limited by the temperature demands for growth. This applies especially to members of the endemic Antarctic species of the order Desmarestiales. In these taxa the northern distribution limit is determined by the temperature requirements for growth of the sporophytes (Wiencke and tom Dieck 1989), which occur only south of the Antarctic convergence in areas with maximum temperatures $\leq 5^{\circ} \mathrm{C}$ allowing growth of their sporophytes. The USTs of their sporophytes and gametophytes as well as the temperature demands for growth of the gametophytes are irrelevant for the explanation of the geographic distribution of these species.

The distribution of Arctic North Atlantic species is often limited both by the USTs and the ULGs (van den Hoek 1982a, b; Breeman 1988; Lüning 1990). In such taxa, distribution limits in the West Atlantic are determined by lethal, high summer temperatures, whereas they are determined in the East Atlantic by high winter temperatures inhibiting reproduction. Examples for species from this group are Laminaria digitata, Chorda filum and Halosiphon tomentosus.

During the ice ages both polar regions were inhospitable for seaweeds. In the Southern Hemisphere the sub-Antarctic islands probably served as refugia. The South American Archipelago may also have hosted species escaping from the coasts of the Antarctic continent (Skottsberg 1964). At the maximum of the last ice age the $5^{\circ} \mathrm{C}$ summer isotherm, the boundary of the Antarctic region just touched the southern tip of South America (CLIMAP project members 1981). Migration of species from the Antarctic continent to South America and vice versa probably occurred along the Scotia Arc, a well-recognized route for animals (Knox and Lowry 1978). In the Northern Hemisphere cold water seaweeds of the Atlantic with ULGs and upper temperature limits for growth at 10 or $15^{\circ} \mathrm{C}$ experienced an extreme reduction in the distribution area during the ice ages (van den Hoek and Breeman 1989). The distribution of these species was compressed by the glaciers in the North and the $10-15^{\circ} \mathrm{C}$ winter isotherm, their southern reproduction boundary. This is the likely explanation for the present depauperate flora in the North West Atlantic. Comparable conditions did not exist in the North Pacific, probably a major reason for the richness of the cold North Pacific.

During periods of lowered temperatures taxa with relatively high temperature demands were able to extend their distribution limits towards the equator. Species with an amphiequatorial distribution e.g. Acrosiphonia arcta (Bischoff and Wiencke 1995a), Urospora penicilliformis (Bischoff and Wiencke 1995b) and Desmarestia viridis/ confervoides (Peters and Breeman 1992) have 
probably crossed the equator during the Pleistocene lowering of the water temperatures in the tropics (Wiencke et al. 1994). The USTs of these taxa are with $25-27^{\circ} \mathrm{C}$ slightly above the minimum tropical sea surface temperatures of $23-25^{\circ} \mathrm{C}$ during the last glaciation (CLIMAP Project members 1981). These results are supported by molecular studies indicating an almost complete sequence identity in amphiequatorial populations of $A$. arcta and D. viridis/confervoides in the fastevolving internal transcribed spacer regions of the ribosomal DNA (van Oppen et al. 1993).

\section{Light demands and depth zonation}

At high latitudes, the radiation regime imposes severe constraints not only in terms of seasonal light availability but also in regard to the vertical distribution of benthic algae (Gómez et al. 1997). Because of the extreme environmental conditions in the eulittoral, polar algae are mainly sublittoral and thus low light demands and tolerance to darkness are a pre-requisite for occurrence down to great depths (Arnoud 1974; Zielinski 1981; Richardson 1979; Klöser et al. 1993; Amsler et al. 1995). An important feature is the dark tolerance of the microscopic developmental stages. Various Antarctic and Arctic seaweeds tolerate a dark period of up to 18 months (tom Dieck 1993; Wiencke 1988, 1990a). Further evaluation of the relation between photosynthetic characteristics and algal zonation in 36 macroalgal species from King George Island (Weykam et al. 1996, Gómez et al. 1997) indicates a high degree of shade adaptation: (a) photosynthetic efficiency $(\alpha)$ is high in all the studied species, reflecting a clear shade adaptation over a broad range of depth; (b) seaweeds growing at depths $>10 \mathrm{~m}$ exhibit low saturation points for photosynthesis $\left(\mathrm{E}_{\mathrm{k}} ;<40\right.$ $\mu \mathrm{mol} \mathrm{m} \mathrm{m}^{-2} \mathrm{~s}^{-1}$ ) irrespective of their taxonomic position; (c) the highest $\mathrm{E}_{\mathrm{k}}$ values $(>50 \mu \mathrm{mol}$ $\mathrm{m}^{-2} \mathrm{~s}^{-1}$ ) are found in species common in upper sublittoral or eulittoral; (d) shallow water species have higher photosynthetic capacity $\left(\mathrm{P}_{\max }\right)$ than species from deeper waters. These data obtained using field material are supported also by results obtained in studies using specimens grown from unialgal cultures from the same study area
(Wiencke et al. 1993; Eggert and Wiencke 2000). The highest degree of shade adaptation with average $E_{k}$ values around $3 \mu \mathrm{mol} \mathrm{m}{ }^{-2} \mathrm{~s}^{-1}$ has been demonstrated in coralline algae from the Ross Sea (Schwarz et al. 2005).

The vertical distribution of dominant Antarctic seaweeds such as Desmarestia or Himantothallus can be extremely wide in contrast to the algal zonation patterns from cold-temperate and temperate regions, where zonation patterns are characterized by narrow belts of species (Lüning 1990). However, no evidence of an acclimation to the prevailing light conditions at different depths could be demonstrated in five species of seaweeds along a depth gradient between $10 \mathrm{~m}$ and $30 \mathrm{~m}$ (Gómez et al. 1997). Apparently, the intrinsic low light requirements for photosynthesis account for these patterns. In the Antarctic spring-summer, due to high water transparency irradiances of PAR around $20 \mu \mathrm{mol} \mathrm{m}{ }^{-2} \mathrm{~s}^{-1}$ reach the depth of $30 \mathrm{~m}$, with $1 \%$ of the surface irradiance present at depths $>40 \mathrm{~m}$ (Gómez et al. 1997). Although these levels are clearly lower than average midday irradiances (30-325 $\mu \mathrm{mol}$ photon $\mathrm{m}^{-2} \mathrm{~s}^{-1}$ ) at $30 \mathrm{~m}$ in some clear temperate and tropical waters (Peckol and Ramus 1988), they exceed reported saturation and compensation points of photosynthesis in many Antarctic seaweeds (Weykam et al. 1996).

As for photosynthesis, the light demands for growth are similarly very low. In microscopic developmental stages of Antarctic seaweeds growth is light saturated already at $4-12 \mu \mathrm{mol}$ $\mathrm{m}^{-2} \mathrm{~s}^{-1}$ (Wiencke 1990a). In young sporophytes of Antarctic Desmarestiales growth is saturated at 15-20 $\mu \mathrm{mol} \mathrm{m} \mathrm{m}^{-2} \mathrm{~s}^{-1}$ (Wiencke and Fischer 1990).

In the case of Arctic species, low light requirements for photosynthesis have also been found in nine species from Spitsbergen (Latala 1990) and in crustose coralline red algae from the high Arctic (Roberts et al. 2002). Meristematic tissue of both juvenile and adult individuals of Laminaria solidungula from the Alaskan high Arctic exhibits $E_{k}$ values between 20 and $30 \mu \mathrm{mol} \mathrm{m}{ }^{-2} \mathrm{~s}^{-1}$, while the average $E_{k}$ value of vegetative blade tissue in adult plants is $38 \mu \mathrm{mol} \mathrm{m} \mathrm{m}^{-2} \mathrm{~s}^{-1}$ (Dunton and Jodwalis 1988). Photosynthetic efficiency $(\alpha)$ is higher than in Laminariales from the temperate region. Both the 
low $\mathrm{E}_{\mathrm{k}}$ and $\alpha$ values indicate strong adaptation to the long period of exposure to darkness in winter under ice cover and in summer during times of high water turbidity. Another feature characterising the dark adaptation of L. solidungula is the low compensation point $\left(\mathrm{E}_{\mathrm{c}}\right)$ for growth close to $0.6 \mu \mathrm{mol} \mathrm{m}{ }^{-2} \mathrm{~s}^{-1}$ (Chapman and Lindley 1980).

Seaweeds able to grow in deep waters have developed metabolic strategies to maximize carbon fixation by avoiding excessive carbon losses due to respiration. Because at great depths, $E_{c}$ for photosynthesis exceed $E_{c}$ values for growth and available irradiances are normally below the levels required for saturation of photosynthesis, carbon assimilation may be just compensating dark respiration. In Antarctic brown algae, dark respiration has a strong seasonal component and during the growth period, respiratory activity may account for a considerable proportion of the gross photosynthesis (Gómez et al. 1995a, b). If one relates the daily light course of the irradiance to the $E_{k}$ value, then the daily period for which plants are exposed to irradiances $>E_{k}$ (denominated $\mathrm{H}_{\text {sat }}$ ) can be estimated. The obtained metabolic daily carbon balance can be regarded as a physiological indicator for the ability to grow in deep waters (Gómez et al. 1997).

Polar seaweeds exposed to marked seasonal changes in daylength exhibit generally $\mathrm{H}_{\text {sat }}$ values $>0$ h only during the short open water season. Laminaria solidungula in a kelp bed in the Alaskan Beaufort Sea at $70{ }^{\circ} \mathrm{N}$ was exposed during August to September 1986 to total $\mathrm{H}_{\text {sat }}$ periods of up to $148 \mathrm{~h}$ (Dunton 1990). This value corresponds to an average daily $\mathrm{H}_{\text {sat }}$ of $3 \mathrm{~h}$. However, depending on the year, the average daily $\mathrm{H}_{\text {sat }}$ may decrease down to $<0.5 \mathrm{~h}$. Year-round underwater light measurements have yielded annual quantum budgets of $45 \mathrm{~mol} \mathrm{~m}^{-2} \mathrm{yr}^{-1}$, the lowest ever documented for kelp populations globally (Dunton 1990). A similar low value, $49 \mathrm{~mol} \mathrm{~m}^{-2} \mathrm{yr}^{-1}$, was already obtained earlier by Chapman and Lindley (1980), values considerably lower than in the temperate L. hyperborea, which receives $71 \mathrm{~mol} \mathrm{~m}^{-2} \mathrm{yr}^{-1}$ (Lüning and Dring 1979).

For Antarctic seaweeds, $\mathrm{H}_{\text {sat }}$ measured during optimum light conditions in spring in five brown and red algae decreases with depth from values close to $14 \mathrm{~h}$ at $10 \mathrm{~m}$ to values between $7 \mathrm{~h}$ and
$12 \mathrm{~h}$ at $30 \mathrm{~m}$ depth (Gómez et al. 1997). For the red algae Palmaria decipiens, Kallymenia antarctica and Gigartina skottsbergii a metabolic carbon balance between 0.6 and $0.8 \mathrm{mg} \mathrm{C} \mathrm{g}^{-1} \mathrm{FW} \mathrm{d}^{-1}$ sets the limits for growth at $>30 \mathrm{~m}$. For Himantothallus grandifolius, which dominates depths below $15 \mathrm{~m}$, the daily carbon balance was low but relatively similar over a range between $10 \mathrm{~m}$ and $30 \mathrm{~m}$, indicating that this species can potentially grow even considerably deeper. Only in Desmarestia anceps is growth clearly limited at $30 \mathrm{~m}$ due to its negative carbon balance at this depth (-1.9 $\mathrm{mg} \mathrm{C} \mathrm{g}^{-1} \mathrm{FW} \mathrm{d}^{-1}$; Gómez et al. 1997). The lower depth distribution limit of the red alga Myriogramme mangini from the South Orkney Islands has been predicted by photosynthetic measurements to be at $23 \mathrm{~m}$ water depth (Brouwer 1996).

Overall, polar seaweeds by virtue of their low light demands are potentially able to grow over large ranges of depths. Depending on the water characteristics the lower depth distribution limit of seaweeds both in the Antarctic and the Arctic is located between $30 \mathrm{~m}$ and $90 \mathrm{~m}$ (Wilce 1994; Wiencke and Clayton 2002). However, other constraints such as competition also control algal zonation. For example, red algae are metabolically able to live at great depths, however, they can be outcompeted by the large canopy brown alga Himantothallus (Klöser et al. 1996). Furthermore, ice abrasion and grazers, e.g. some invertebrate and demersal fishes, have a strong influence on zonation patterns (Iken 1996; Iken et al. 1997).

Antarctic seaweeds are not only strongly shadeadapted but can also cope with high light conditions in summer due to their ability for dynamic photoinhibition, a photoprotective mechanism by which excessive energy absorbed is rendered harmless by thermal dissipation (Krause and Weis 1991; Demmig-Adams and Adams III 1992). This capability is best expressed in species from the eulittoral. Upper and mid sublittoral species show a more or less pronounced decrease in photosynthetic activity during high light stress and full recovery during subsequent exposure to dim light (Hanelt et al. 1997). In contrast, deep water and understory species recover only slightly and slowly, indicating photodamage. Similar findings as these on Antarctic seaweeds have been demonstrated 
also in a detailed analysis of seaweeds from Spitsbergen (Hanelt 1998). Similarly, UV radiation is now also regarded as a key factor affecting the depth zonation of seaweed assemblages. This topic will be treated in detail in a separate paper in this issue (Bischof et al. in press).

\section{Effect of salinity, temperature and desiccation on supra-and eulittoral seaweeds}

Until now few ecophysiological studies have been undertaken on the salinity acclimation in polar seaweeds (Karsten et al. 1991a, b; Jacob et al. 1991, 1992a). These papers indicate that cells of eulittoral Chlorophyta from the Antarctic survive salinities between 7 psu and 102 psu with a low rate of mortality, and that most taxa grow, photosynthesize and respire optimally under normal seawater conditions with rather broad tolerances between 7 psu and 68 psu. The supralittoral Prasiola crispa ssp. antarctica even grows between $0.3 \mathrm{psu}$ and $105 \mathrm{psu}$. Consequently, eulittoral and supralittoral macroalgae from Antarctica can be characterized as euryhaline organisms.

Osmotic acclimation in response to salinity changes is a fundamental mechanism of salinity tolerance that conserves intracellular homeostasis (Kirst 1990). The acclimation process in Antarctic Chlorophyta involves the metabolic control of the cellular concentrations of osmolytes. The major inorganic osmolytes are potassium, sodium and chloride (Karsten et al. 1991b; Jacob et al. 1991), the cellular concentrations of which can be rapidly adjusted with low metabolic energy costs, especially compared to the cost of organic osmolyte biosynthesis or degradation (Kirst 1990). However, protein and organelle function, enzyme activity and membrane integrity in seaweeds are adversely affected by increased electrolyte concentration. Hence, the biosynthesis and accumulation of organic osmolytes in the cytoplasm permits the generation of low water potentials without incurring metabolic damage. For these organic compounds that are tolerated by the metabolism even at high intracellular concentrations, the term 'compatible solute' was introduced by Brown and Simpson (1972).
All Antarctic Chlorophyta studied possess as main organic osmolytes the carbohydrate sucrose and the imino acid proline, and-with the exception of Prasiola-a third compound, $\beta$-dimethylsulphoniumpropionate (DMSP). Prasiola is able to synthesize polyols such as sorbitol and ribitol instead of DMSP. The concentrations of all osmolytes are actively regulated as a function of the external salinity. Because of its physicochemical properties proline is one of the most potent organic osmolytes, which not only balances salinity stress, but also may stimulate enzymatic activity. This imino acid is the most important osmolyte in ice-algae too (Thomas and Dieckmann 2002). Sucrose is also a wellknown osmotically active compound in many higher and lower plants, and also exhibits a cryoprotective function. The osmotic function of DMSP seems to be unique to Antarctic Chlorophyta in comparison with temperate ones, because of very high intracellular concentrations and the strong biosynthesis and accumulation with increasing salinities. In addition, DMSP acts as compatible solute and cryoprotectant (Karsten et al. 1996a). Polyols such as sorbitol are the most water-like molecules, and therefore represent not only ideal osmolytes and compatible solutes, but exert a function as rapidly available respiratory substrate (e.g. under desiccation) and as antioxidant (Karsten et al. 1996b). The presence of high concentrations of three organic osmolytes in Antarctic Chlorophyta may be related to the extremely cold habitat suggesting that, besides their osmotic role, these solutes are playing multiple functions in metabolism such as cryoprotectants. In the case of $P$. crispa ssp. antarctica the broad salinity tolerance is also assisted by the thickness and mechanical properties of the cell walls (Jacob et al. 1992a). Another ultrastructual feature of Prasiola cells is the absence of vacuoles under hypososmotic conditions up to full seawater and the formation of vacuoles at high salinities. Under the latter conditions, they may serve as compartments accumulating inorganic ions.

Compared to the eulittoral Chlorophyta, much less is known of the ecophysiology of the red algae Bangia atropurpurea and Porphyra endiviifolium from Antarctica. The few data on temperature requirements for growth and 
survival indicate eurythermal characteristics for both Rhodophyta, i.e. they survive temperatures up to $21-22^{\circ} \mathrm{C}$ (Bischoff-Bäsmann and Wiencke 1996). Studies on closely related species of both genera from other biogeographic regions clearly indicate an extremely broad tolerance of all environmental factors, which is based on a high metabolic flexibility (Karsten et al. 1993; Karsten and West 2000). Bangia and Porphyra synthesize and accumulate three isomeric heterosides with different physiological functions as osmolytes, compatible solutes and soluble carbon reserve.

Besides hypersaline conditions decreasing temperatures also strongly stimulate the biosynthesis and accumulation of DMSP in Antarctic Chlorophyta (Karsten et al. 1996a). In addition, DMSP not only stabilises the cold-labile model enzyme lactate dehydrogenase and malate dehydrogenase extracted from Acrosiphonia arcta during several freezing and thawing cycles, but also stimulates both enzyme activities at in situ concentrations. Consequently, DMSP acts as an effective cryoprotectant (Nishiguchi and Somero 1992). Recent studies on Antarctic Prasiola and sea ice diatoms indicate the presence of ice-binding proteins (IBP) that modify the shape of growing intracellular ice crystals during freezing (Raymond and Fritsen 2001). IBPs do not lower the freezing point, they rather seem to prevent damage to membranes by the inhibition of the recrystallization of ice (Raymond and Knight 2003). During recrystallization small ice particles typically grow to large grains of ice, which may physically injure cell membranes. Consequently, IBPs act as effective structural cryoprotectants.

In the eulittoral and supralittoral zone, low temperatures combined with high irradiance represent a particular challenge to algal physiology. At low temperature, and, thus, reduced enzyme activities and decreased turn-over velocity of D1 reaction centre protein in photosystem II (Davison 1991; Andersson et al. 1992; Aro et al. 1993), a persisting high irradiance of PAR may result in increased electron pressure in photosynthesis. This may ultimately result in the generation of reactive oxygen species within the Mehler reaction (Polle 1996) and increase oxidative stress (Asada and Takahashi 1987). The consequences of increased oxidative stress are chronic photoinhibition/photoinactivation, bleaching of photosynthetic pigments, peroxidation of membrane lipids and enhanced degradation of D1 protein (Aro et al. 1993; Osmond 1994). Hitherto this phenomenon is hardly studied in Antarctic macroalgae (Hanelt et al. 1994, 1997). However, the limited information available suggests that polar algae from the eulittoral, such as the brown alga Adenocystis utricularis, may overcome radiation stress at low temperatures by their ability for dynamic photoinhibition/photoprotection (Osmond 1994), which proceeds much faster than in sublittoral algae (Hanelt et al. 1994, 1997). The rate of inhibition seems to be independent of temperature. The underlying mechanism is still unexplored, but possible explanations include the adaptation of enzymes involved in the D1 repair cycle at low temperatures, and the insignificant role of D1 in photoinhibition and recovery of photosynthesis in Antarctic macroalgae (Hanelt et al. 1994). The ability for fast photoinhibition and to completely halt photosynthesis under steadily decreasing temperatures at constant irradiance levels was also found in eulittoral Fucus distichus from Arctic Spitsbergen (Bischof and Walter, unpublished data). Here, a critical temperature level to initiate pronounced photoinhibition was found to be $-3^{\circ} \mathrm{C}$. As soon as temperatures fall below this threshold, photosynthesis becomes rapidly inhibited, and photosynthetic quantum yield completely ceases at $-15^{\circ} \mathrm{C}$. Recovery from freezing temperature proceeds almost in reverse, with a rapid increase in quantum yield as soon as temperatures climb above $-3^{\circ} \mathrm{C}$. By their ability to reduce photosynthetic quantum yield, polar eulittoral algae seem to be able to avoid increasing oxidative stress under low temperature conditions. However, some species seem to apply other strategies of photoprotection under low temperature, since Becker (1982) reported for Antarctic Prasiola photosynthetic activity down to $-15^{\circ} \mathrm{C}$. The capacity to photosynthesize as efficiently in air (when hydrated) as in water, in combination with a high affinity for inorganic carbon, has been described for a temperate species of this genus (Raven and Johnston 1991).

Desiccation is a strong stress parameter in supralittoral species. Air exposed thalli of 
Prasiola crispa loose $75 \%$ of the cellular water during the first $6 \mathrm{~h}$ of desiccation (Jacob et al. 1992b). A water loss of more than $90 \%$ leads to irreversible damage. Growth rates after reimmersion in seawater depend on the thallus water content and the length of the desiccation period. Few ultrastructural changes were found after desiccation. As after salinity stress, the very thick cell walls of the species and the absence of vacuoles are regarded as prerequisites to survive periods of desiccation (Jacob et al. 1992b).

Although there is a lack of knowledge of the ecophysiological performance of many eulittoral macroalgae from Antarctica, the known data clearly indicate broad tolerances against the prevailing environmental, often extreme parameters. In particular, the biochemical capability to synthesize and accumulate various protective compounds seems to be the main prerequisite for long-term survival.

The response of polar seaweeds to inorganic and organic pollutants has only randomly been investigated so far. Especially brown algae take up the radionuclide contaminant ${ }^{99} \mathrm{Tc}$ very strongly (Topcuoglu and Fowler 1984; Gwynn et al. 2004). The uptake mechanisms and the actual effect of ${ }^{99} \mathrm{Tc}$ are, however, not yet investigated. With respect to the oil spill of the Bahia Paraiso near Anvers Island, Antarctic Peninsula (Kennicutt II et al. 1990), there were no observable differences between oiled and non-oiled sites with respect to the percentage cover of either sublittoral macroalgal overstory or crustose coralline algae (Amsler et al. 1990). Similarly, Dunton et al. (1990) could not determine significant effects on photosynthesis in Porphyra endiviifolium and Palmaria decipiens. On the other hand, Stockton (1990) reported that the principal intertidal alga, Urospora sp. turned brown soon after the spill. The degree of damage certainly depends on the amount and type of material released.

\section{Seasonality of reproduction and the physiological characteristics of microscopic developmental stages}

The heteromorphic life history of large brown algae is characterized by the development of perennial sporophytes and a reduction of the gametophyte generation (Clayton 1988). The ultimate step in this evolutionary trend is observed in members of the Fucales and Ascoseirales, which lack free-living gametophytes. In Laminariales and Desmarestiales, free-living gametophytes are still present; however, they are morphologically inconspicuous, generally consisting of microscopic filaments and they are important mainly in sexual reproduction. It has been suggested that the dissimilar reproductive phase expression in large kelps may be primarily associated with a differential response to wave action (Neushul 1972), herbivory (Slocum 1980; Lubchenco and Cubit 1980; Dethier 1981) or physical factors such as temperature and light (Kain 1964; Lüning and Neushul 1978; Lüning 1980b; Fain and Murray 1982; Novaczek 1984; tom Dieck 1993). Early developmental stages of seaweeds (zoospores, gametophytes and small sporophytes) are shade-adapted organisms unlike the adult sporophytes (Kain 1964; Amsler and Neushul 1991; Gómez and Wiencke 1996a; Dring et al. 1996). The different physiological performance of the heteromorphic phases has implications for algal ecology: reproduction, metabolic performance (e.g. photosynthesis) and growth are seasonally synchronized improving survival under changing environmental conditions (Lüning 1990). Thus, light adaptation is an important functional character connecting the different stages of life in these species.

In Antarctic Desmarestiales reproduction and further development of gametophytes and sporophytes are governed by the photoperiod. Culture studies carried out on all members of the Antarctic Desmarestiales indicate that life history depends strongly on the seasonal variation of daylengths. In general, the development of gametangia, fertilization (oogamy) and the formation of the early stages of sporophytes take place in winter in all Antarctic species of Desmarestiales, whereas growth of sporophytes begins with increasing daylengths in late winter-spring. In Himantothallus grandifolius, Desmarestia anceps and D. menziesii, gametophytes become fertile under short day conditions only (Wiencke 1990a; Wiencke and Clayton 1990; Wiencke et al. 1995, 1996). In D. antarctica and Phaeurus antarcticus 
gametogenesis occurs both in short and long days. In these species seasonality is controlled by the sporophytic stage. Sporophytes become fertile in culture at daylengths between $6 \mathrm{~h}$ and $8 \mathrm{~h}$ light per day and the developing gametophytes formed gametangia soon after germination (Clayton and Wiencke 1990; Wiencke 1990a; Wiencke et al. 1991). Similarly, in the Arctic kelp, Laminaria solidungula, sori are produced in winter (November) just before the growth of the lamina begins, but spore release does not occur until the following spring (Hooper 1984). Gametophytes become fertile in this species under short day conditions only, not under long days and short days combined with a night-break regime (Bartsch, pers. comm.). Irradiance levels $<5 \mu \mathrm{mol} \mathrm{m}{ }^{-2} \mathrm{~s}^{-1}$ are necessary to induce gametogenesis and fertilization in Antarctic Desmarestiales (Wiencke 1990a; Wiencke and Clayton 1990; Wiencke et al. 1995, 1996). The upper temperature limit for gametogenesis is $5^{\circ} \mathrm{C}$ in $D$. antarctica (Wiencke et al. 1991), a feature probably common in Desmarestiales from Antarctica.

Interestingly, all of the Antarctic Desmarestiales studied to date show in situ fertilization, i. e. the juvenile sporophytes remain attached to the gametophytes (Wiencke et al. 1995, 1996). This adds new evidence for the importance of the gametophytic generation on the early stages of the large sporophytes. In terms of ecological significance, one may speculate that the recruitment of sporophytes and consequently the observed dominance of these species may be conditioned by the survival (or mortality) of the gametophytes.

The development of gametophytes or at least their reproductive capacity appears to be constrained by high light conditions suggesting that the fitness associated with the winter development of gametophytes lies partly in a differentiation of light requirements for photosynthesis. For example, in Desmarestia menziesii early stages of sporophytes and gametophytes are better suited to live under low light conditions than adult sporophytes: photosynthetic efficiency $(\alpha)$ measured in these phases is five times higher than in adult sporophytes (Gómez and Wiencke 1996a). The differences in pigment allocation, cross section pathlength of radiation and general development between the different stages account for the light harvesting efficiency at low irradiance (Ramus 1981). In filamentous or thin sheet-like thalli, pigment-based photosynthesis follows a linear curve, whereas in thick morphs, characterized by several cell layers and low ratios of photosynthetic to non-photosynthetic tissues, photosynthesis becomes uncoupled from the pigment content due to a greater self-shading (Ramus 1978).

In general, early life stages have higher dark respiration rates than adult ones, with consequences for light compensation points $\left(\mathrm{E}_{\mathrm{c}}\right)$. Because of their high respiration rates, $E_{c}$ in gametophytes and small sporophytes are not significantly lower than in adult sporophytes, whereas the photon fluence rate required for saturation $\left(E_{k}\right)$ is considerably higher in adult sporophytes due to lower $\alpha$ values. Photosynthesis in adult sporophytes is saturated at significantly higher irradiances $\left(30 \mu \mathrm{mol} \mathrm{m} \mathrm{m}^{-2} \mathrm{~s}^{-1}\right)$ than in gametophytes or juvenile sporophytes $\left(16 \mu \mathrm{mol} \mathrm{m}{ }^{-2} \mathrm{~s}^{-1}\right)$. Despite their very high respiratory activities sporophytes and gametophytes from several Antarctic Desmarestiales show light saturation of growth at irradiances close to $10 \mu \mathrm{mol} \mathrm{m}{ }^{-2} \mathrm{~s}^{-1}$ (Wiencke 1990a; Wiencke and Fischer 1990) indicating that growth is not constrained by such low irradiances (Gómez and Wiencke 1996b).

The capacity of gametophytes and small sporophytes to grow and photosynthesize under low light conditions may be regarded as adaptive and allows the algae to survive under the seasonally changing light environment in polar regions. During winter, when incident irradiance is low and daylength is short, high photosynthetic rates and growth of gametophytes and juvenile sporophytes are favoured in virtue of their higher surface-area/volume ratio, higher pigment content and more efficient light use.

\section{Seasonal growth and photosynthesis}

In polar regions, seasons are characterized by short periods of favourable light conditions and extended periods of darkness due to polar nights and sea ice covering during winter (see chapter 2). The seasonal development of macroalgae is 
generally triggered by light, temperature and/or nutrient conditions (Chapman and Craigie 1977; Lüning 1980a; Lüning and tom Dieck 1989). As temperatures and nutrient levels show only a small variation over the year in Antarctic waters (see chapter 2), seasonality of Antarctic seaweeds depends mainly on variable light conditions and, especially, daylengths. Thus, assessment of the seasonal development of Antarctic species in long-term culture experiments is possible simply by mimicking the seasonally fluctuating daylengths at the collecting site (Wiencke 1990a, b). Seasonality of growth and photosynthesis as well as seasonal formation of gametes/spores can be monitored much more closely than possible in the field. The results of these studies complement the available fragmentary field observations and indicate that the phenology of Antarctic macroalgae can be controlled in the laboratory. Data on Arctic species are so far based on field studies only.

Antarctic seaweeds follow two different growth strategies in order to cope with the strong seasonality of the light regime (Wiencke 1990a, b; Dummermuth and Wiencke 2003). One group, mainly endemics, begins to grow under short day conditions in late winter-spring, even under sea ice, and reaches maximal growth in spring. Some species even reproduce in winter. This group has been classified as season anticipators sensu Kain (1989). In these species annual growth and reproduction is most probably based on photoperiodism and circannual rhythms, triggered or synchronized by daylength as shown for species from other phytogeographic regions (Lüning and tom Dieck 1989; tom Dieck 1991; Lüning and Kadel 1993; Schaffelke and Lüning 1994). To this group belong the brown algae Desmarestia menziesii, D. antarctica, D. anceps, Himantothallus grandifolius, Phaeurus antarcticus, Ascoseira mirabilis (Wiencke 1990a; Drew and Hastings 1992; Gómez et al. 1995a, 1996b; Gómez and Wiencke 1997) and the red algae Palmaria decipiens, Delesseria salicifolia, Gymnogongrus antarcticus, G. turquetii, Hymenocladiopsis crustigena, Kallymenia antarctica, Phyllophora ahnfeltioides (Gain 1912; Wiencke 1990b; Weykam et al. 1997; Dummermuth and Wiencke 2003). The second group, mainly composed of
Antarctic-cold temperate species, are season responders sensu Kain (1989). Species in this group start growth later coinciding with favourable light conditions in spring and summer. They react directly to changing environmental conditions and show an opportunistic life strategy. To this group belong the brown alga Adenocystis utricularis (Wiencke 1990a), the red algae Iridaea cordata (Weykam et al. 1997) and Gigartina skottsbergii (Wiencke 1990b), and the green algae Enteromorpha bulbosa and Acrosiphonia arcta (Wiencke 1990b).

As for growth, a strong seasonal pattern of photosynthetic performance was found in longterm culture studies (Weykam and Wiencke 1996; Weykam et al. 1997; Gómez and Wiencke 1997; Lüder et al. 2001a, 2002,2003) and in field experiments (Gutkowski and Maleszewski 1989; Drew and Hastings 1992; Gómez et al. 1995b, 1997). In the brown algal season anticipators optimal photosynthetic rates are highest in late winter (September) for A. mirabilis (Gómez et al. 1995b) or in spring (November) for Himantothallus grandifolius (Drew and Hastings 1992) and D. menziesii (Gómez et al. 1997). In these species, morpho-functional processes strongly regulate photosynthetic seasonality: In spring respiration rates increase in all thallus parts, indicating growth activity in the basal meristem powered by remobilization of carbohydrates from the distal thallus part (Gómez et al. 1995b) as in Laminaria species (Lüning et al. 1973; Schmitz 1981). This is supported by the decrease of the storage carbohydrate laminaran in late winter and spring in A. mirabilis (Gómez and Wiencke 1998). The low molecular weight compound, mannitol, is presumably used as substrate for respiration during the period of active growth. This is reflected by its low levels during the main growth period. In late summer, the mannitol content increases significantly in the basal and middle region. In the distal region it may serve as substrate for light independent carbon fixation or is stored as laminaran which attains its highest content in the distal thallus part (Gómez and Wiencke 1998). Similar results have been obtained in D. menziesii (Gómez and Wiencke 1997; Gómez et al. 1998). In contrast, the season responder Adenocystis utricularis (Gutkowski and 
Maleszewski 1989) features lowest photosynthetic capacity in spring and highest in autumn (no data in summer available).

In red algae, seasonality has been studied in particular with respect to the acclimation of light harvesting capacities. The light requirements for growth and photosynthesis of the Antarctic season anticipator Palmaria decipiens and in the Antarctic season responder Iridaea cordata are very low (Wiencke 1990b; Wiencke et al. 1993; Weykam et al. 1997). P. decipiens develops new blades during Antarctic late winter/spring (Wiencke 1990b) and starts growth in Antarctic winter (July) with optimum in spring (Wiencke 1990b). The photosynthetic capacity $\left(\mathrm{P}_{\max }\right.$ and $\left.\mathrm{ETR}_{\max }\right)$ and photosynthetic efficiency $\left(\alpha\right.$ and $\left.F_{v} / F_{m}\right)$ are, as growth, maximal in Antarctic spring (Weykam and Wiencke 1996; Lüder et al. 2001a). A strong relationship between the seasonal patterns of photosynthesis and pigment contents has been demonstrated in P. decipiens (Lüder et al. 2001a). Photosynthetic capacity and pigment contents increase in parallel continuously during the entire mid autumn, winter and spring. There is a positive correlation between phycobiliproteins and photosynthetic capacity, but a weaker correlation between Chl $a$ and photosynthetic capacity. Phycobiliproteins are used to increase number and size of phycobilisomes, the main light harvesting antennae of red algae (Lüder 2003). Photosynthetic efficiency is optimal in autumn, winter and spring. During Antarctic summer, $P$. decipiens reduces its photosynthetic apparatus to a minimum: Photosynthetic efficiency, photosynthetic capacity, and the contents of phycobiliproteins and Chl $a$ tissue are low (Lüder et al. 2001a). The existence of two phycobilisome forms with different aggregation states in $P$. decipiens might be considered as an advantage for a rapid acclimation to changes in environmental light conditions (Lüder et al. 2001b). Studies on seasonal assembly of the light harvesting antennae in $P$. decipiens have shown that both phycobilisome forms are extremely variable in size and number during the entire year (Lüder 2003).

The effect of darkness on the seasonal growth pattern in two Antarctic red macroalgae has been examined in long-term culture experiments by Weykam et al. (1997). Growth rates in the
Antarctic season anticipator $P$. decipiens are low or even negative during darkness but increase strongly after re-illumination with maximal growth in early spring. The content of floridean starch decreases gradually in the dark and drops suddenly powering the formation of new blades in winter (early August) after 6 months exposure to darkness (Weykam et al. 1997). This feature supports the theory that seasonal growth is controlled in season anticipators either by photoperiodism or cirannual rhythms. In contrast, the Antarctic season responder Iridaea cordata develops no blades during darkness and starts growth more slowly after re-illumination with maximal growth rates in late spring.

Photosynthetic capacity and efficiency in $P$. decipiens is almost unaffected by 2 months in darkness albeit an initial increase in pigments (Weykam et al. 1997; Lüder et al. 2002; Lüder 2003). After 4 months in darkness the light harvesting antennae, the phycobilisomes, are degraded. One of the two forms of phycobilisomes in $P$. decipiens disappears (Lüder 2003). This is followed later by a degradation of the chl $a$-containing inner antennae (Lüder et al. 2002). At the end of the 6 months dark period, $P$. decipiens has lost its ability to photosynthesize (Lüder et al. 2002; Weykam et al. 1997). After re-exposure to light, pigments are synthesized rapidly and enhance photosynthetic performance to normal values within a week (Lüder et al. 2002). The season responder I. cordata, in contrast, maintains its photosynthetic apparatus functional during exposure to darkness (Weykam et al. 1997). This species is therefore better able to grow in regions with less predictable light conditions.

In contrast to the Antarctic there is a great seasonal variation in the Arctic not only with respect to daylength but also with respect to the macronutrient levels, which are high in winter and low in summer (see chapter 2). Nevertheless, the seasonal growth of the few seaweeds from the Arctic studied so far is triggered primarily by daylength and is supported by high nutrient levels in winter, as discussed below. The Arctic kelp Laminaria solidungula and the Arctic-cold temperate L. saccharina are clear season anticipators. In L. solidungula new blade formation is initiated in autumn under conditions of decreasing 
daylengths. Maximal growth rates occur in latewinter to early spring under thick ice and decline in summer and autumn in the ice-free period (Chapman and Lindley 1980; Dunton 1985). In the Alaskan Beaufort Sea, L. solidungula fronds continue to grow under a turbid ice canopy that produces conditions of nearly complete darkness, even under continuous daylight (Dunton 1990). In comparison, L. saccharina appears to delay nearly all of its annual growth to a brief period in late spring when light first starts to penetrate the water column during sea ice break-up (Dunton 1985).

The energy required to survive darkness and to start blade formation in winter is provided by mobilization of stored carbon reserves, accumulated during the previous summer, when inorganic nitrogen becomes available similar as in L. longicruris (Hatcher et al. 1977; Gagne et al. 1982; Chapman and Craigie 1978; Dunton and Dayton 1995). In L. solidungula, mobilization of these reserves occurs during the dark 9-month ice covered period, when the plant completes over $90 \%$ of its annual linear growth, and results in a carbon deficit where up to $30 \%$ of its original total carbon content is depleted before photosynthetic production begins in early summer (Dunton and Schell 1986). During the summer open-water period (July to October), when the concentration of inorganic-N is nearly undetectable in coastal waters, high rates of photosynthetic carbon fixation result in carbon storage and not in blade elongation in L. solidungula (Dunton and Schell 1986).

The utilization of stored photosynthate for growth was first reported by Lüning (1971), who found that Laminaria hyperborea in northern Europe accumulated reserves during its period of slow growth in summer to support the formation and growth of a new blade the following spring. Subsequent work by Lüning (1979) on three Laminaria species in the North Sea confirmed the importance of these reserves in L. hyperborea, but he also suggested that a circannual rhythm was involved in the regulation of seasonal growth since no one particular factor appeared responsible for triggering the onset of new growth. Lüning's hypothesis was later proved correct; the onset of short daylengths in autumn, combined with lower temperatures and normally low levels of inorganic-N were important cues that led to both sorus formation (Lüning, 1988) and new blade formation in several species of kelp (Lüning and tom Dieck 1989). But of all these cues, elaborate experimental studies demonstrated that daylength was most important in the setting of internal clocks in species that possess circannual rhythms which control the periodicity in linear growth (Lüning 1991; Lüning and Kadel 1993).

\section{Elemental and nutritional contents}

The most commonly used indicator of nutrient limitation in marine algae is the carbon to nitrogen ratio $(\mathrm{C}: \mathrm{N})$, with low values indicative of nitrogen replete growth conditions. To date, $\mathrm{C}: \mathrm{N}$ data have been reported from 54 species of macroalgae in Antarctica including 8 species of green algae, 36 species of red algae, and 10 species of brown algae (Dhargalkar et al. 1987; Weykam et al. 1996; Dunton 2001; Peters et al. 2005). Reported C:N ratios (on a weight:weight basis) range from a minimum of 5.0 to a maximum of 23.6 with an overall mean of 10.2, indicating that most if not all of the macroalgal species are not nitrogen limited (Peters et al. 2005). Likewise, tissue nitrogen levels are relatively high and almost always above the $1.5 \%$ level thought to be indicative of nitrogen replete growth conditions (Rakusa-Suszczewski and Zielinski 1993; Weykam et al. 1996; Peters et al. 2005). Generally, C:N values are much lower than most reported outside of Antarctica (a mean C:N value for temperate and tropical marine plants is approximately 19; Atkinson and Smith 1983) and presumably result from the high nitrate concentrations present in coastal Antarctic waters throughout the year (Weykam et al. 1996; Peters et al. 2005), although morpho-functional processes such as storage and remobilization of $\mathrm{C}$ and $\mathrm{N}$ in response to growth requirements are also important (Gómez and Wiencke 1998). Along the Antarctic Peninsula, there is a slight trend for somewhat lower $\mathrm{C}: \mathrm{N}$ values at King George Island $\left(62^{\circ} 14^{\prime} \mathrm{S}, 58^{\circ} 40^{\prime} \mathrm{W}\right)$ compared to Anvers Island $\left(64^{\circ} 46^{\prime} \mathrm{S}, 64^{\circ} 03^{\prime} \mathrm{W}\right)$, suggesting a possibility of minor geographically based variation, but there was no apparent variation between 
early and late growing seasons (Weykam et al. 1996; Dunton 2001; Peters et al. 2005).

We are aware of only one published report of $\mathrm{C}: \mathrm{N}$ ratios or nitrogen contents in macroalgae from the Arctic. Henley and Dunton (1995) reported on seasonal and within-thallus variation in the kelps Laminaria solidungula and L. saccharina from the Alaskan Arctic. C:N ratios were relatively low (approximately 11.6-13.5, converted from atom:atom to weight:weight basis) and tissue nitrogen levels relatively high $(1.9-3.0 \%)$ in second year blades of both species regardless of season. In first year blades, however, $\mathrm{C}: \mathrm{N}$ ratios increased significantly from early to late growing seasons in both species (from approx. 9.4 to 18.3 in L. solidungula and 9.8 to 24.8 in $L$. saccharina). This correlated with significant decreases in tissue nitrogen (Henley and Dunton 1995) but laboratory studies suggest important roles for both light and nitrogen availability in driving these patterns (Henley and Dunton 1997).

Macroalgae are a potentially important nutritional source for a variety of Antarctic animals (Iken et al. 1998; Dunton 2001) and macroalgal nutritional parameters, particularly protein content, can be important determinants of palatability to consumers (e.g., Horn and Neighbors 1984; Duffy and Paul 1992; Bolser and Hay 1996). Although we are unaware of any published reports of protein or other nutritional parameters in macroalgae from the Arctic, protein and other nutritional content data are available from 44 species of Antarctic macroalgae including 7 species of green algae, 28 species of red algae, and 9 species of brown algae (Czerpak et al. 1981; Dhargalkar et al. 1987; Rakusa-Suszczewski and Zielinski 1993; Gómez and Westermeier 1995; Gómez and Wiencke 1998; Peters et al. 2005). Protein levels are usually considerably higher when compared to temperate or tropical macroalgae in which protein contents were determined with similar methodology (Peters et al. 2005) although this is not always true (Gómez and Westermeier 1995). By itself, this would suggest that Antarctic macroalgae should be relatively palatable to consumers and the fact that this is not so for a majority of species (Amsler et al. 2005a, b) is probably related to chemical defenses as described in chapter 11. Peters et al. (2005) reported that there was no significant correlation between protein and nitrogen contents across all 40 species they examined, brown algae alone, or red algae late in the growing season but that there was a significant, positive correlation for red algae early in the growing season. In a more detailed study focused on the endemic brown alga $A s$ coseira mirabilis, Gómez and Wiencke (1998) reported a significant, positive correlation between protein and nitrogen content in the distal portion of the thallus but not in middle or basal portions. The general lack of correlation between protein and nitrogen content indicates that protein production is not constrained by nitrogen availability and is probably another reflection of the high nutrient environment present in coastal antarctic waters. This general lack of correlation also indicates that older methods which estimate protein concentrations in macroalgae based on nitrogen contents are less appropriate for use with Antarctic macroalgae.

\section{Chemical and physical defences against herbivory and fouling}

Defence mechanisms against grazing pressure, and fouling organisms, including bacteria and pathogens can be critical to the success and survival of polar seaweeds. Seaweeds constitute a potential food and carbon source for many kinds of heterotrophic organisms, e.g. amphipods, gastropods, sea urchins or fishes. Tropical and temperate algal species often display physical defensive mechanisms such as structural toughness, physiological defensive mechanisms such as low nutritional content (see chapter 10 of this review) or chemical defensive mechanisms such as a high content or an induction of allelopathic chemicals. Allelopathy refers to the usually detrimental effects that seaweeds have on other interacting organisms through the production of secondary metabolites.

The incidence of herbivory in Arctic as well as Antarctic shallow water systems is low but several organisms depend fully or in part on seaweeds as a food source in the Antarctic (Brand 1974; Richardson 1977; Iken et al. 1997, 1999; Iken 1999; Dunton 2001; Graeve et al. 2001) and the 
Arctic (Lippert et al. 2001; Wessels et al. 2006; Dunton and Schell 1987). A comprehensive investigation of palatability in 35 fleshy seaweeds from the Antarctic Peninsula (Anvers Island) against a sympatric (occurring within the same geographical region) fish and sea star algal consumer showed that about $60 \%$ and $80 \%$, respectively, of the algae were unpalatable (Amsler et al. 2005a). These included all dominant overstory brown algae and a variety of abundant red algal species of the region. Unpalatable algal species were extracted and the palatability of organic extracts was tested after incorporation into artificial foods (Amsler et al. 2005a). Again, the majority of species were unpalatable as at least one extract type to the fish, sea star and an amphipod consumer. No overall correlation in feeding patterns could be established with tissue toughness or nutritional content of the algae (Amsler et al. 2005a; Peters et al. 2005) although toughness could play a role in the unpalatability of some particular macroalgal species to amphipods (Huang et al. 2006).

Only two fleshy red macroalgae, Iridaea cordata and Phyllophora antarctica, occur in McMurdo Sound, the southernmost location of open ocean conditions (Miller and Pearse 1991). Thallus fragments and paper disks laced with organic extracts of these species were tested in a phagostimulation assay where the retention time of a test or control food was measured over the mouth of the sympatric sea urchin, Sterechinus neumayeri. Algal treatments were retained for significantly shorter times compared to controls (blank paper disks and disks with a feeding stimulant), indicating the presence of deterrent chemicals in both red algal species (Amsler et al. 1998).

Along the Antarctic Peninsula, within-thallus variation of chemical and physical defences was tested for the ecologically important brown macroalgae Desmarestia anceps and D. menziesii (Fairhead et al. 2005a). This study found that overall chemical defences are prevalent, but some tissue types depend more on physical than chemical protection, such as holdfasts. In the highly differentiated $D$. anceps, high allocation of chemical and physical defences to holdfast and stipe tissue was consistent with predictions of optimal defence theory (Rhoades 1979), which assumes that defences are costly and therefore should be allocated to the most valuable and vulnerable tissue types.

A recent study of palatability using 19 abundant macroalgal species from Spitsbergen (Arctic) showed that most species were at least moderately palatable to a sympatric amphipod and sea urchin (Wessels et al. 2006). Consumption by both herbivores differed among algal species and preference patterns for algae differed for both herbivores, indicating species-specific preference patterns. Tissue-specific palatability of stipe and blade tissues of the kelp species differed for both herbivores with no preference in sea urchins and a preference for Laminaria blades and Alaria stipes in the amphipod (Wessels et al. 2006). Although not explicitly discussed by the authors, higher defences in kelp stipes compared to blades could be explained by resource allocation considerations as mentioned above for Antarctic brown algae. Generally, however, and in contrast to the findings for Antarctic seaweeds, unpalatability in Arctic seaweeds seems to be more related to structural than chemical properties of the algae (Wessels et al. 2006). Only one red algal species, Ptilota gunneri, showed indications of being chemically defended against the two grazers.

In addition to deterring grazers, organic extracts of all Antarctic macroalgal species tested (2 from McMurdo, 22 from Anvers Island) also were toxic to sympatric diatoms (Amsler et al. $2005 b$ ). To the best of our knowledge, no comparable information is available on antifouling properties in Arctic seaweeds.

Little is known about the particular compounds that may be active in chemical defence against herbivores and epiphytes in either of the two polar regions. Phlorotannins are a class of polyphenolic compounds found exclusively in brown algae. Their ecological functions, especially as anti-herbivore agents for temperate and tropical species have frequently been discussed (Targett and Arnold 2001; Amsler and Fairhead 2006). Phlorotannins were shown to be present in Antarctic brown algae (Iken 1996; Iken et al. 2001; Fairhead et al. 2005b), but their ecological significance remains ambiguous (Iken et al. 2001; 
Iken unpubl. data). Microscopic studies in the Arctic brown seaweed, Laminaria solidungula, have shown that phlorotannins play an important role in wound healing (Lüder unpubl. data) as in the temperate Australasian Ecklonia radiata (Lüder and Clayton 2004). An induction of phlorotannin production in the cells of the wound area was evident after mechanical wounding simulating a grazer attack. Phlorotannins at the wound area probably deter bacteria or other microbes and may prevent the algae from being eaten further. In addition, phlorotannins bound in cell walls (Schoenwaelder 2002) may form a barrier for grazers or fouling organisms in $L$. solidungula (Lüder unpubl. data).

A variety of other secondary metabolites such as terpenes, furanones and acetogenins have been isolated and structurally resolved in Antarctic seaweeds (esp. red algae, for review see Amsler et al. 2001; Ankisetty et al. 2004), although the ecological significance of most of these compounds in grazer or fouler deterrence remains to be established. Chemical screening of organic extracts of Antarctic seaweeds revealed that no chemicals containing nitrogen are present (Amsler et al. 2005a) even though it had been hypothesized that the nitrogen-replete conditions in Antarctic coastal waters should promote the synthesis of nitrogenous compounds.

Another group of compounds shown to be present in Arctic and Antarctic seaweeds are volatile halogenated organic compounds (VHOC) (Laturnus 1996, 2001; Laturnus et al. 1996). These compounds are released continuously in substantial amounts by Arctic brown algae, while red algae release only trace amounts. The deterrent effect of VHOC on grazers is often assumed but so far has been detected only at exceptionally high and probably ecologically irrelevant concentrations (Amsler and Fairhead 2006).

Chemical defences in polar seaweeds may also be employed for protection against deleterious environmental conditions. In polar regions, UVB radiation due to the thinning ozone layer can be particularly harmful. Red algae from both polar regions have been shown to produce mycosporine-like amino acids (MAA) as photoprotective substances (e.g., McClintock and Karentz 1997;
Hoyer et al. 2001; Aguilera et al. 2002). For detailed review on MAAs in polar seaweeds see Bischof et al. in press.

\section{Future perspectives}

Although considerable progress has been achieved in recent years, our present knowledge of seaweeds from polar regions is still fragmentary. Due to the extreme remoteness of the polar regions and the infrequency of scientific studies even the basic features of the polar seaweed floras such as the numbers of recorded species are not firmly established. More studies are therefore needed to precisely document the biodiversity of Arctic and Antarctic seaweeds. If such studies are combined with molecular investigations it should be possible to demonstrate, for example, the presence of gene flow between populations of the same species in the Antarctic/Arctic and the adjacent cold-temperate regions. Alternatively, where gene flow is absent, divergence times between the populations can be estimated. Furthermore, molecular studies could definitively demonstrate seaweed dispersal routes and give a much clearer pattern of the biogeographic relationships between the polar and cold-temperate regions than is presently available.

More culture studies are necessary especially on seaweeds from the Arctic. None of the truly endemic Arctic species is in culture today and no data are available on the ecophysiological properties of these species. In this context it would be very interesting to know whether the relatively short cold water history of the Arctic could have promoted the evolution of species with temperature demands as low as in the Antarctic region. Further, culture studies have been proven to give pertinent insights into the life strategies of polar seaweeds not only with respect to the temperature requirements and geographic distribution but also with respect to the light requirements and depth zonation. Even the phenology of seaweeds could be monitored in culture studies under simulated polar light conditions.

Such studies should ideally be combined with field experiments. Data on the underwater radiation regime would allow an estimate of benthic 
primary production in different water depths through the determination of the metabolic carbon balance. Apart from studies with the Arctic Laminaria solidungula, the physiological performance of seaweeds in winter is obscure. Only baseline field studies are available together with a few papers based on laboratory studies. Reproduction, growth and photosynthetic rates, the content of pigments and cryoprotective substances, the elemental and nutritional composition as well as enzyme activities must be monitored over the entire year to understand the life strategy of these species in more detail.

With respect to elemental and nutritional content the major questions are, first, whether the greater availability of nitrogen in Antarctic waters and the apparent uncoupling of nitrogen availability and protein content alter our understanding about resource allocation in seaweeds that come from studies in other systems. Secondly, if the higher overall protein concentrations in Antarctic macroalgae indeed makes them more nutritious to herbivores compared to algae from other regions (which remains to be experimentally tested), does the response of herbivores to the (often few) palatable Antarctic seaweeds alter ideas about herbivore feeding ecology that are based on lower latitude systems? In this respect the functioning of the internal long distance transport system in members of the Desmarestiales and Ascoseirales in comparison with members of the Laminariales is obscure and must be investigated with respect to the allocation of storage compounds.

The few data available on community ecology make further studies in this area very urgent. In this respect, the interesting hypothesis that the relative lack of filamentous epiphytic seaweeds in Antarctica could be due to a relatively high level of mesoherbivory needs to be tested.

In this context more studies are needed on herbivory and chemical defence of seaweeds. Chemical deterrence should be tested against a larger set of potential herbivores so that the importance of chemical defence can be interpreted on a community-wide scale; this also requires a better understanding of herbivore abundances and grazing rates. Spatial coverage of chemical defences against herbivores should be extended to obtain a more comprehensive understanding of their importance in seaweeds on an ocean-wide basis. Few compounds have been identified so far as being active in chemical defence. Detailed knowledge will allow better comparisons with what is known from temperate and tropical systems. A question of interest concerning seaweeds from all regions is whether chemical defenses are constitutive, i.e. consistently present in the alga, or induced by the attack of herbivores? This may be particularly useful for answering the question of the yet unsolved roles of phlorotannins in brown algae: constitutive levels did not show clear patterns in herbivore deterrence, but microscopic studies show that wounding can lead to high local accumulation of phlorotannins. Whether this has broader impact needs to be addressed.

The ecophysiology of supra- and eulittoral species needs to be investigated in more detail in field studies. To survive in the intertidal zone, algae need to protect their metabolism and particularly their photosynthetic apparatus against temporary light stress conditions, heat stress, cold, freezing and also against pollution. Virtually nothing is known about protective mechanisms in polar seaweeds. Therefore, a detailed analysis of such mechanisms ensuring homeostasis and functional integrity of the photosynthetic apparatus in supra-and eulittoral polar seaweeds is necessary. Changes in the expression of photosynthetic key proteins (D1, RubisCO, ATPsynthase), and the synthesis of specific protective proteins (Heat Shock Proteins, Chaperonins, Cryoproteins) and protective metabolites (osmolytes, cryoprotectants, antioxidants, sunscreens etc.) in relation to stress exposure should be studied in the field, mesocosms and controlled laboratory experiments. So far, gene expression, biosynthetic pathways and metabolic regulation, for example, are scientific fields almost unexplored in polar seaweeds. In particular, the quest for potential cryoproteins represents a novel aspect in plant research in general. The results of such studies will substantially increase the understanding of biochemical adaptation to plant life in extreme environments.

All these studies need to be complemented by a detailed monitoring of the environmental 
conditions especially in the supra-and eulittoral. Our knowledge in this area is also still fragmentary.

Acknowledgements Many results described in this paper would not have been possible without the generous financial support by the Deutsche Forschungsgemeinschaft, the German Academic Exchange Service, the European Commission, the Alexander von Humboldt Foundation, the Australian Research Council and the US National Science Foundation. This help is greatly acknowledged here. Finally, we thank Akira Peters and another unknown referee for constructive comments on the manuscript.

\section{References}

Aguilera J, Bischof K, Karsten U, Hanelt D, Wiencke C (2002) Seasonal variation in ecological patterns in macroalgae from an Arctic fjord. II. Pigment accumulation and biochemical defence systems against high light stress. Mar Biol 140:1087-1095

Amsler CD, Fairhead VA (2006) Defensive and sensory chemical ecology of brown algae. Adv Bot Res 43:1-91

Amsler CD, Neushul M (1991) Photosynthetic physiology and chemical composition of spores of the kelps Macrocystis pyrifera, Nereocystis luetkeana, Laminaria farlowii, and Pterygophora californica (Phaeophyceae). J Phycol 27:26-34

Amsler CD, Laur DR, Quetin LB, Rowley RJ, Ross R, Neushul M. (1990) Quantitative analysis of the vertical distribution of overstory macroalgae near Anvers Island. Antarctica. Antarctic J US 25:201-202

Amsler CD, Rowley RJ, Laur DR, Quetin LB, Ross RM (1995) Vertical distribution of Antarctic Peninsular macroalgae: cover, biomass and species composition. Phycologia 34:424-430

Amsler CD, McClintock JB, Baker BJ (1998) Chemical defenses against herbivory in the Antarctic marine macroalgae Iridaea cordata and Phyllophora antarctica (Rhodophyceae). J Phycol 34:53-59

Amsler CD, Iken KB, McClintock JB, Baker BJ (2001) Secondary metabolites from Antarctic organisms and their ecological implications. In: McClintock JB, Baker BJ (eds) Marine chemical ecology. CRC Press, Boca Raton, pp 267-300

Amsler CD, Okogbue IN, Landry DM, Amsler MO, McClintock JB, Baker BJ (2005a) Potential chemical defenses against diatom fouling in Antarctic macroalgae. Bot Mar 48:318-322

Amsler CD, Iken K, McClintock JB, Amsler MO, Peters KJ, Hubbard JM, Furrow FB, Baker BJ (2005b) Comprehensive evaluation of the palatability and chemical defenses of subtidal macroalgae from the Antarctic Pensinsula. Mar Ecol Prog Ser 294:141-159

Andersson B, Salter AH, Virgin I, Vass I, Styring S (1992) Photodamage to photosystem II-primary and secondary events. J Photochem Photobiol B: Biol 15:15-31
Ankisetty S, Nandiraju S, Win H, Park YC, Amsler CD, McClintock JB, Baker JA, Diyabalanage TK, Pasaribu A, Singh MP, Maiese WM, Walsh RD, Zaworotko MJ, Baker BJ (2004) Chemical investigation of predator-deterred macroalgae from the Antarctic Peninsula. J Nat Prod 67:1295-1302

Arnoud PM (1974) Contributions à la binomie marine bentique des régions Antarctiques et subantarctiques. Thethys 6:465-653

Arnold KE, Manley SL (1985) Carbon allocation in Macrocystis pyrifera (Phaeophyta): intrinsic variability in photosynthesis and respiration. $\mathrm{J}$ Phycol 21:147-167

Aro EM, Virgin I, Andersson B (1993) Photoinhibition of photosystem II. Inactivation, protein damage and turnover. Biochim Biophys Acta 1143:113-134

Asada K, Takahashi M (1987) Production and scavenging of active oxygen in photosynthesis. In: Kyle DJ, Osmond CB, Arntzen CJ (eds) Photoinhibition. Topics in photosynthesis, vol 9. Elsevier Science Publishers, Amsterdam, pp 89-109

Atkinson M, Smith S (1983) C:N:P ratios of benthic marine plants. Limnol Oceanogr 28:568-574

de Baar HWJ (1994) Von Liebig's law of the minimum and plankton ecology. Progr Oceoanogr 33:347-386

de Baar HJW, de Jong JTM, Bakker DCE, Löscher BM, Veth C, Bathmann U, Smetacek, V (1995) Importance of Iron for Plankton Blooms and Carbon Dioxide Drawdown in the Southern Ocean. Nature 373:412-415

Becker EW (1982) Physiological studies on Antarctic Prasiola crispa and Nostoc commune at low temperatures. Polar Biol 1:99-104

Bird CJ, Mc Lachlan JL (1992) Seaweed flora of the Maritimes, I. Rhodophyta-The red algae. Biopress Ltd. Bristol

Bischof K, Gómez J, Molis M, Hanelt D, Karsten U, Lüder, UH, Roleda M, Zacher K, Wiencke C (2006) UV radiation shapes seaweed communities. Rev Environ Sci Biotechnol in press

Bischoff B, Wiencke C (1993) Temperature requirements for growth and survival of macroalgae from DiskoIsland (Greenland). Helgol Mar Res 47:167-191

Bischoff B, Wiencke C (1995a) Temperature ecotypes and biogeography of Acrosiphoniales (Chlorophyta) with Arctic-Antarctic disjunct and Arctic/cold-temperate distributions. Eur J Phycol 30:19-27

Bischoff B, Wiencke C (1995b) Temperature adaptation in strains of the amphi-equatorial green alga Urospora penicilliformis (Acrosiphoniales) - biogeographical implications. Mar Biol 122:681-688

Bischoff-Bäsmann B, Wiencke C (1996) Temperature requirements for growth and survival of Antarctic Rhodophyta. J Phycol 32:525-535

Bolser RC, Hay ME (1996) Are tropical plants better defended? Palatability and defenses of temperate vs tropical seaweeds. Ecology 77:2269-2286

Bolton JJ, Lüning K (1982) Optimal growth and maximal survival temperatures of Atlantic Laminaria species (Phaeophyta) in culture. Mar Biol 66:89-94 
Brand TE (1974) Trophic interactions and community ecology of the shallow-water marine benthos along the Antarctic Peninsula. PhD Dissertation, University of California, Davis, pp 1-220

Breeman AM (1988) Relative importance of temperatures and other factors in determining geographic boundaries of seaweeds: experimental and phenological evidence. Helgoländer Meeresunters 42:199-241

Brouwer PEM (1996) In situ photosynthesis and estimated annual production of the red macroalga Myriogramme mangini in relation to underwater irradiance at Signy Island (Antarctica). Antarctic Sci 8:245-252

Brown AD, Simpson JR (1972) Water relations of sugartolerant yeasts: the role of intracellular polyols. J General Microbiol 72:589-591

Buggeln RG (1983) Photoassimilate translocation in brown algae. Progr Phycol Res 2:283-332

Cabello-Pasini A, Alberte RS (2001) Expression of carboxylating enzymes in Laminaria setchelli (Phaeophyceae). Phycologia 40:351-358

Chapman ARO, Craigie JS (1977) Seasonal growth in Laminaria longicruris: relation with dissolved inorganic nutrients and internal reserves of nitrogen. Mar Biol 40:197-205

Chapman ARO, Craigie JS (1978) Seasonal growth in Laminaria longicruris: relations with reserve carbohydrate storage and production. Mar Biol 46:209-213

Chapman ARO, Lindley JE (1980). Seasonal growth of Laminaria longicruris in the High Arctic in relation to irradiance and dissolved nutrient concentration. Mar Biol 57:1-5

Clarke DL (1990) Arctic Ocean ice cover; geologic history and climatic significance. In: Grantz A, Johnson L, Sweeney JL (eds) The Arctic Ocean region. Geol. Soc. America, Boulder Colo, pp 53-62

Clarke A, Barnes KA, Hodgson DA (2005) How isolated is Antarctica. Trends Ecol Evol 20:1-3

Clayton MN (1987) Isogamy and a fucalean type of life history in the Antarctic brown alga Ascoseira mirabilis (Ascoseirales, Phaeophyta). Bot Mar 30:447-455

Clayton, MN (1988) Evolution and life histories of brown algae. Bot Mar 31:379-387

Clayton MN, Ashburner CM (1990) The anatomy and ultrastructure of "conducting channels" in Ascoseira mirabilis (Ascoseirales, Phaeophyceae). Bot Mar 33:63-70

Clayton MN, Wiencke C (1990) The anatomy, life history and development of the Antarctic brown alga Phaeurus antarcticus (Desmarestiales, Phaeophyceae). Phycologia 29:303-315

Clayton MN, Wiencke C, Klöser H (1997) New records of temperate and sub-Antarctic marine benthic macroalgae from Antarctica. Polar Biol 17:141-149

CLIMAP Project Members (1981) Seasonal re constructions of the earths surface at the last glacial masimum. The Geol. Soc. of America Map and Chart Service MC-36, Washington DC

Cormaci M, Furnari G, Scammacca B (1992) The benthic algal flora of Terra Nova Bay (Ross Sea, Antarctica). Bot Mar 35:541-552
Crame JA (1993) Latitudinal range fluctuations in the marine realm through geological time. Trends Ecol Evol 8:162-266

Cross WE, Wilce RT, Fabijan MF (1987). Effects of experimental releases of oil and dispersed oil on Arctic nearshore macrobenthos. III, Macroalgae. Arctic 40(Suppl. 1):211-219

Czerpak R, Mical A, Gutkowski R, Siegien I (1981) Chemism of some species of Antarctic macroalgae of the genera Adenocystis, Himantothallus, Leptosomia, and Monostroma. Pol Polar Res 2:95-107

Davey MC (1989) The Effects of freezing and desiccation on photosynthesis and survival of terrestrial Antarctic algae and cyanobacteria. Polar Biol 10:29-36

Davison IR (1991) Environmental effects on algal photosynthesis: temperature. J Phycol 27:2-8

Deacon GER (1937) The hydrology of the Southern Ocean. Discovery Rep 15:125-152

DeLaca TE, Lipps JH (1976) Shallow-water marine associations, Antarctic Peninsula. Antarctic J 11:12-20

Delépine R, Lamb JM, Zimmermann MH (1966) Preliminary report on the vegetation of the Antarctic Peninsula. Proc 5th Int Seaweed Symp, pp 107-116

Demmig-Adams B, Adams III WW (1992) Photoprotection and other responses of plants to high light stress. Annu Rev Plant Physiol Plant Mol Biol 43:599-626

Dethier MN (1981) Heteromorphic algal life histories: the seasonal pattern and response to herbivory of the brown crust, Ralfsia californica. Oecologia (Berl.) 49:333-339

Dhargalkar V, Reddy C, Deshmukhe G, Unatawale A (1987) Biochemical composition of some benthic marine algae of the Vestfold Hills. Antarctica Indian J Mar Sci 16:269-271

tom Dieck I (Bartsch) (1991) Circannual growth rhythm and photoperiodic sorus induction in the kelp Laminaria setchellii (Phaeophyta). J Phycol 27:341350

tom Dieck I (1992) North Pacific and North Atlantic digitate Laminaria species (Phaeophyta): hybridisation experiments and temperature responses. Phycologia 31:147-163

tom Dieck I (1993) Temperature tolerance and survival in darkness of kelp gametophytes (Laminariales, Phaeophyta): ecological and biogeographical implications. Mar Ecol Prog Ser 100:253-264

Dieckmann G, Reichardt W, Zielinski K (1985) Growth and production of the seaweed, Himantothallus grandifolius, at King George Island. In: Siegfried WR, Condy PR, Laws RM (eds) Antarctic nutrient cycles and food webs. Springer-Verlag, Berlin Heidelberg, pp 104-108

Drew EA (1977) The physiology of photosynthesis and respiration in some Antarctic marine algae. $\mathrm{Br}$ Antarct Surv Bull 46:59-76

Drew EA, Hastings RM (1992) A year-round ecophysiological study of Himantothallus grandifolius (Desmarestiales, Phaeophyta) at Signy Island. Antarctica. Phycologia 31:262-277 
Dring MJ, Makarov V, Schoschina E, Lorenz M, Lüning K (1996) Influence of ultraviolet radiation on chlorophyll fluorescence and growth in different life history stages of three species of Laminaria (Phaeophyta). Mar Biol 126:183-191

Duffy J, Paul V (1992) Prey nutritional quality and effectiveness of chemical defenses against tropical reef fishes. Oecologia 90:333-339

Dummermuth AL, Wiencke C (2003) Experimental investigation of seasonal development in six Antarctic red macroalgae. Antarct. Sci. 15:449-457

Dunton KH (1985) Growth of dark-exposed Laminaria saccharina (L.) Lamour and Laminaria solidungula J. Ag (Laminariales: Phaeophyta) in the Alaskan Beaufort Sea. J Exp Mar Biol Ecol 94:181-189

Dunton KH (1990) Growth and production in Laminaria solidungula: relation to continuous underwater light levels in the Alaskan high Arctic. Mar Biol 106:297304

Dunton KH (1992) Arctic biogeography: the paradox of the marine benthic fauna and flora. Trends Ecol Evol 7:183-189

Dunton KH (2001) $\delta^{15} \mathrm{~N}$ and $\delta^{13} \mathrm{C}$ measurements of Antarctic Peninsula fauna: trophic relationships and assimilation of benthic seaweeds. Am Zool 41:99-112

Dunton, KH, Dayton, PK (1995) The biology of high latitude kelp. In: Skjoldal HR (ed) Ecology of fjords and coastal waters: proceedings of the Mare Nor symposium on the ecology of fjords and coastal waters, Tromso, Norway, 5-9 December 1994. Elsevier, Amsterdam, pp 499-507

Dunton KH, Jodwalis CM (1988) Photosynthetic performance of Laminaria solidungula measured in situ in the Alaskan High Arctic. Mar Biol 98:277-285

Dunton KH, Schell DM (1986) Seasonal carbon budget and growth of Laminaria solidungula in the Alaskan High Arctic. Mar Ecol Prog Ser 31:57-66

Dunton KH, Schell DM (1987) Dependence of consumers on macroalgal (Laminaria solidungula) carbon in an arctic kelp community: $\delta^{13} \mathrm{C}$ evidence. Mar Biol 93:615-625

Dunton KH, Schonberg SV (2000) The benthic faunal assemblage of the Boulder Patch kelp community. In: Johnson SR, Truett JC (eds) The natural history of an Arctic oil field. Academic Press, San Diego, pp 372-397

Dunton KH, Reimnitz E, Schonberg S (1982) An arctic kelp community in the Alaskan Beaufort Sea. Arctic 35:465-484

Eggert A, Wiencke C (2000) Adaptation and acclimation of growth and photosynthesis of five Antarctic red algae to low temperatures. Polar Biol 23:609-618

Fain SR, Murray SN (1982) Effects of light and temperature on net photosynthesis and dark respiration of gametophytes and embryonic sporophytes of Macrocystis pyrifera. J Phycol 18:92-98

Fairhead VA, Amsler CD, McClintock JB, Baker BJ (2005a) Within-thallus variation in chemical and physical defences in two species of ecologically dominant brown macroalgae from the Antarctic Peninsula. J Exp Mar Biol Ecol 322:1-12
Fairhead VA, Amsler CD, McClintock JB, Baker BJ (2005b) Variation in phlorotannin content within two species of brown macroalgae (Desmarestia anceps and D. menziesii) from the Western Antarctic Peninsula. Polar Biol 28:680-686

Falkowski PG, Raven J (1997) Aquatic photosynthesis. Blackwell Science

Gagne J, Mann K, Chapman ARO (1982) Seasonal patterns of growth and storage in Laminaria longicruris in relation to differing patterns of availability of nitrogen in the water. Mar Biol 69:91-101

Gain L (1912) La flore algologique des régions antarctiques et subantarctiques. In: Charcot J (ed) Deuxième expédition Antarctique française (1908-1910). Sciences naturelles: Documents scientifiques, tome 8 . Masson et Companie, Paris, pp 1-218

Gerland S, Lind B, Dowdall M, Karcher M, Kolstad AK (2003) ${ }^{99} \mathrm{Tc}$ in seawater in the West Spitsbergen Current and adjacent areas. J Environ Radioactivity 69:119-127

Godley EJ (1965) Botany of the southern zone. Exploration to 1843 , Tuatara $13: 140-181$

Gómez I, Lüning K (2001) Constant short-day treatment of outdoor-cultivated Laminaria digitata prevents summer drop in growth rate. Eur J Phycol 36:391-395

Gómez I, Westermeier R (1995) Energy contents and organic constituents in Antarctic and south Chilean marine brown algae. Polar Biol 15:597-602

Gómez I, Wiencke C (1996a) Photosynthesis, dark respiration and pigment contents of gametophytes and sporophytes of the Antarctic brown alga Desmarestia menziesii. Bot Mar 39:149-157

Gómez, Wiencke C (1996b) Seasonal growth and photosynthetic performance of the Antarctic macroalga Desmarestia menziesii (Phaeophyceae) cultivated under fluctuating Antarctic daylengths, Bot Acta 110:25-31

Gómez I, Wiencke C (1997) Seasonal growth and photosynthetic performance of the Antarctic macroalga Desmarestia menziesii (Phaeophyceae) cultivated under fluctuating Antarctic daylengths. Bot Acta 110:25-31

Gómez I, Wiencke C (1998) Seasonal changes in C, N, and major organic compounds and their significance to morphofunctional processes in the endemic Antarctic brown alga Ascoseira mirabilis. Polar Biol 19:115-124

Gómez I, Thomas DN, Wiencke C (1995a) Longitudinal profiles of growth, photosynthesis and light independent carbon fixation in the Antarctic brown alga Ascoseira mirabilis. Bot Mar 38:157-164

Gómez I, Wiencke C, Weykam G (1995b) Seasonal photosynthetic characteristics of the brown alga Ascoseira mirabilis from King George Island (Antarctica). Mar Biol 123:167-172

Gómez I, Wiencke C, Thomas DN (1996) Variations in photosynthetic characteristics of the Antarctic marine brown alga Ascoseira mirabilis in relation to thallus age and size. Eur J Phycol 31:167-172

Gómez I, Weykam G, Wiencke C (1998) Seasonal photosynthetic metabolism and major organic compounds in the marine brown alga Desmarestia menziesii from King George Island (Antarctica). Aquat Bot 60:105-118 
Gómez I, Weykam G, Klöser H, Wiencke C (1997) Photosynthetic light requirements, daily carbon balance and zonation of sublittoral macroalgae from King George Island (Antarctica). Mar Ecol Progr Ser 148:281-293

Graeve M, Dauby P, Scailteur Y (2001) Combined lipid, fatty acid and digestive tract content analyses: a penetrating approach to estimate feeding modes of Antarctic amphipods. Polar Biol 24:853-862

Gutkowski R, Maleszewski S (1989) Seasonal changes of the photosynthetic capacity of the Antarctic macroalga Adenocystis utricularis (Bory) Skottsberg. Polar Biol 10:145-148

Gutt J (2001) On the direct impact of ice on Marine Benthic communities, a review. Polar Biol 24:553-564

Gwynn JP, Dowdall M, Gerland S, Selnæs ØG, Wiencke C (2004) Technetium-99 in Arctic marine algae from Kongsfjorden. Svalbard Ber Polarforsch Meeresforsch 492:35-45

Hanelt D (1998) Capability of dynamic photoinhibition in Arctic macroalgae is related to their depth distribution. Mar biol 131:361-369

Hanelt D, Jaramillo J, Nultsch W, Senger S, Westermeier R (1994) Photoinhibitioin as a regulative mechanism of photosynthesis in marine algae of Antarctica. Ser Cient INACH 44:67-77

Hanelt D, Melchersmann B, Wiencke C, Nultsch W (1997) Effects of high light stress on photosynthesis of polar macroalgae in relation to depth distribution. Mar Ecol Prog Ser 149:255-266

Hanelt D, Tüg H, Bischof K, Gross C, Lippert H, Sawall T, Karsten U, Wiencke C (2001) Light regime in an Arctic fjord: a study related to Stratospheric Ozone depletion as a basis for determination of UV effects on algal growth. Mar Biol 138:649-658

Hanelt D, Wiencke C, Bischof K (2003) Photosynthesis in marine Macroalgae. In: Larkum AW, Douglas SE, Raven JA (eds) Photosynthesis in algae. Kluwer Academic Publisher, Dordrecht, pp 413-435

Hatcher BG, Chapman ARO, Mann KH (1977) An annual carbon budget for the kelp Laminaria longicruris. Mar Biol 44:85-96

Healey FP (1972) Photosynthesis and respiration of some Arctic seaweeds. Phycologia 11:267-271

Hempel G (1987) Die Polarmeere - ein biologischer Vergleich. Polarforsch 57:173-189

Henley WJ, Dunton KH (1995) A seasonal comparison of carbon, nitrogen, and pigment content in Laminaria solidungula and L. saccharina (Phaeophyta) in the Alaskan Arctic. J Phycol 31:325-331

Henley WJ, Dunton KH (1997) Effects of nitrogen supply and continuous darkness on growth and photosynthesis of the arctic kelp Laminaria solidungula. Limnol Oceanogr 42:209-216

van den Hoek C (1982a) Phytogeographic distribution groups of benthic marine algae in the North Atlantic Ocean. A review of experimental evidence from life history studies. Helgoländer Meeresunters 35:153-214

van den Hoek C (1982b) The distribution of benthic marine algae in relation to the temperature regulation of their life histories. Biol J Linn Soc 18:1-144 van den Hoek C, Breeman AM (1989) Seaweed biogeography in the North Atlantic: where are we now? In: Garbary DJ, South GR (eds) Evolutionary biogeography of the marine algae of the North Atlantic. NATO ASI Series, Vol. G 22, Springer-Verlag, Berlin, Heidelberg, pp 57-86

Hooper RG (1984) Functional adaptations to the polar environment by the arctic kelp, Laminaria solidungula. Br Phycol J 19:194

Hop H, Pearson T, Hegseth EN, Kovacs KM, Wiencke C, Kwasniewski S, Eiane K, Mehlum F, Gulliksen B, Wlodarska-Kowalczuk M, Lydersen C, Weslawski JM, Cochrane S, Gabrielsen GW, Leakey RJG, Lønne OJ, Zajaczkowski M, Falk-Petersen S, Kendall M, Wängberg S-Å, Bischof K, Voronkov AY, Kovaltchouk NA, Wiktor J, Poltermann M, di Prisco G, Papucci C, Gerland S (2002) The ecosystem of Kongsfjorden, Svalbard. Polar Res 21:167-208

Horn M, Neighbors M (1984) Protein and nitrogen assimilation as a factor in predicting the seasonal macroalgal diet of the monkeyface prickleback. Trans Am Fish Soc 113:388-396

Hoyer K, Karsten U, Sawall T, Wiencke C (2001) Photoprotective substances in Antarctic macroalgae and their variation with respect to depth distribution, different tissues and developmental stages. Mar Ecol Prog Ser 211:117-129

Huang YM, McClintock JB, Amsler CD, Peters KJ, Baker BJ (2006) Feeding rates of common Antarctic gammarid amphipods on ecologically important sympatric macroalgae. J Exp Mar Biol Ecol 329:55-65

Iken K (1996) Trophic relations between macroalgae and herbivores in Potter Cove (King George Island, Antarctica). Ber Polarforsch Meeresforsch 201:1-206. (in German)

Iken K (1999) Feeding ecology of the Antarctic herbivorous gastropod Laevilacunaria Antarctica. J Exp Mar Biol Ecol 236:133-148

Iken K, Barrera-Oro ER, Quartino ML, Casaux RJ, Brey T (1997) Grazing in the Antarctic fish Notothenia coriiceps: evidence for selective feeding on macroalgae. Ant Sci 9:386-391

Iken K, Quartino M, Barrera Oro E, Palermo J, Wiencke C, Brey T (1998) Trophic relations between macroalgae and herbivores. Ber Polarforsch Meeresforsch 299:258-262

Iken K, Quartino ML, Wiencke C (1999) Histological identification of macroalgae from stomach contents of the Antarctic fish Notothenia coriiceps gives new insights in its feeding ecology. Mar Ecol 20:11-18

Iken KB, Amsler CD, Hubbard JM, McClintock JB, Baker BJ (2001) Preliminary results on secondary metabolites from Antarctic brown algae and their ecological relevance. J Phycol 37:25-26. (Suppl.)

Jacob A, Kirst GO, Wiencke C, Lehmann H (1991) Physiological responses of the Antarctic green alga Prasiola crispa ssp. antarctica to salinity stress. J Plant Physiol 139:57-62

Jacob A, Lehmann H, Kirst GO, Wiencke C (1992a) Changes in the ultrastructure of Prasiola crispa ssp. antarctica under salinity stress. Bot Acta 105:41-46 
Jacob A, Wiencke C, Lehmann H, Kirst GO (1992b) Physiology and ultrastructure of desiccation in the green alga Prasiola crispa from Antarctica. Bot Mar 35:297-303

Jerlov NG (1976) Marine optics. Elsevier, Amsterdam

Johnston AM, Raven J (1986) Dark carbon fixation studies on the intertidal macroalga Ascophyllum nodosum (Phaeophyta). J Phycol 22:483-485

Kain (Jones) JM (1964) Aspects of the biology of Laminaria hyperborea. III. Survival and growth of gametophytes. J Mar Biol Assoc UK 44:415-433

Kain JM (1989) The seasons in the subtidal. Br Phycol J 24:203-215

Karsten U, West JA (2000) Living in the intertidal zone seasonal effects on heterosides and sun-screen compounds in the red alga Bangia atropurpurea (Bangiales). J Exp Mar Biol Ecol 254:221-234

Karsten U, Wiencke C, Kirst GO (1991a) The effect of salinity changes upon physiology of eulittoral green macroalgae from Antarctica and Southern Chile. I. Cell viability, growth, photosynthesis and dark respiration. J Plant Physiol 138:667-673

Karsten U, Wiencke C, Kirst GO (1991b) The effect of salinity changes upon physiology of eulittoral green macroalgae from Antarctica and Southern Chile. II. Inorganic ions and organic compounds. J Exp Bot 42:1533-1539

Karsten U, Barrow KD, King RJ (1993) Floridoside, Lisofloridoside and D-isofloridoside in the red alga Porphyra columbina: seasonal and osmotic effects. Plant Physiol 103:485-491

Karsten U, Kück K, Vogt C, Kirst GO (1996a) Dimethylsulfoniopropionate production in phototrophic organisms and its physiological function as a cryoprotectant. In: Kiene RP (ed) Biological and environmental chemistry of DMSP and related sulfonium compounds. Plenum Press, New York, pp 143-153

Karsten U, Barrow KD, Nixdorf O, King RJ (1996b) The compatibility of unusual organic osmolytes from mangrove red algae with enzyme activity. Aust J Plant Physiol 23:577-582

Kennicutt II MC, et al (1990) Oil spillage in Antarctica. Environ Sci Technol 24:620-624

Kerby WN, Evans LV (1983) Phosphoenolpyruvate carboxykinase activity in Ascophyllum nodosum (Phaeophyceae). J Phycol 19:1-3

Kirst GO (1990) Salinity tolerance of eukaryotic marine algae. Annu Rev Plant Physiol Plant Mol Biol 41:21-53

Kirst GO, Wiencke C (1995) Ecophysiology of polar algae. J Phycol 31:181-199

Kjellman FR (1883) The algae of the Arctic Sea. Boktryckeriet, Stockholm

Klöser, H (1994) Descripción Basica de la Caleta Potter y Costas Abiertas Adyacentes. Dirección Nacional del Antártico; reporte de datos: Estructura y Dinamica de un Ecosistema Costero Antártico, Estación Cientifica "Teniente Jubany" en la Isla 25 de Mayo (King George Island), Islas Shetland del Sur. Contributión 419B
Klöser H, Ferreyra G, Schloss I, Mercuri G, Laturnus F, Curtosi A (1993) Seasonal variation of algal growth conditions in sheltered Antarctic bays: the example of Potter Cove (King Goerge Island, South Shetlands). J Mar Systems 4:289-301

Klöser H, Quartino ML, Wiencke C (1996) Distribution of macroalgae and macroalgal communities in gradients of physical conditions in Potter Cove, King George Island, Antarctica. Hydrobiologia 333:1-17

Knebel G (1936) Monographie der Algenreihe Prasiolales, insbesonder von Prasiola crispa. Hedwigia 75:1-120

Knox GA, Lowry JK (1978) A comparison between the benthos of the Southern Ocean and the North Polar Ocean with special reference to the Amphipoda and the Polychaeta. In: Dunbar JM (ed) 'Polar Oceans' Proc. SCOR/SCAR polar ocean conference, Montreal 1974, pp 423-462

Konar B, Iken K (2005) Competitive dominance among sessile marine organisms in a high Arctic boulder community. Polar Biol 29:61-64

Krause GH, Weis E (1991) Chlorophyll fluorescence and photosynthesis: the basics. Annu Rev Plant Physiol Plant Mol Biol 42:313-349

Kremer BP (1981a) Metabolic implications of non-photosynthetic carbon fixation in brown macroalgae. Phycologia 20:242-250

Kremer BP (1981b) Aspects of carbon metabolism in marine macroalgae. Oceanogr Mar Biol Annu Rev 19:41-94

Küppers U, Kremer BP (1978) Longitudinal profiles of carbon dioxide capacities in marine macroalgae. Plant Physiol 62:49-53

Lamb IM, Zimmermann MH (1977) Benthic marine algae of the Antarctic Peninsula, Antarctic research series 23, Biology of the Antarctic Seas V, Paper 4, pp 129-229

Latala A (1990) Photosynthesis and respiration of some marine benthic algae from Spitsbergen. Polar Res 8:303-308

Laturnus F (1996) Volatile halocarbons released from Arctic macroalgae. Mar Chem 55:359-366

Laturnus F (2001) Marine macroalgae in polar regions as natural sources for volatile organohalogens. Environ Sci Pollut Res 8:103-108

Laturnus F, Wiencke C, Klöser H (1996) Antarctic macroalgae - sources of volatile halogenated organic compounds. Mar Environ Res 41:169-181

Lee RKS (1980) A catalogue of the marine algae of the Canadian Arctic. Natl Mus Can Nat Sci Publ Bot 9:1-83

Lippert H, Iken K, Rachor E, Wiencke C (2001) Macrofauna associated with macroalgae at Kongsfjord (Spitsbergen) - species composition and distribution on abundant macroalgal species. Polar Biol 24:512-522

Lubchenco J, Cubit J (1980) Heteromorphic life histories of certain marine algae as adaptations to variations in herbivory. Ecology 61:676-687

Lüder UH (2003) Acclimation of the photosynthetic apparatus of the endemic Antarctic red macroalga Palmaria decipiens to seasonally changing light conditions. Ber Polarforsch Meeresforsch 469:141 pp 
Lüder UH, Clayton MN (2004) Induction of phlorotannins in the brown macroalga Ecklonia radiata (Laminariales, Phaeophyta) in response to simulated herbivory - the first microscopic study. Planta 218:928-937

Lüder UH, Knoetzel J, Wiencke C (2001a) Acclimation of photosynthesis and pigments to seasonally changing light conditions in the endemic Antarctic red macroalga Palmaria decipiens. Polar Biol 24:598-603

Lüder UH, Knoetzel J, Wiencke C (2001b) Two forms of phycobilisomes in the Antarctic red macroalga Palmaria decipiens (Palmariales, Florideophyceae). Physiol Plant 112:572-581

Lüder UH, Knoetzel J, Wiencke C (2002) Acclimation of photosynthesis and pigments during and after six months of darkness in Palmaria decipiens (Rhodophyta) - a study to simulate Antarctic winter sea ice cover. J Phycol 38:904-913

Lund S (1951) Marine algae from Jörgen Brönlunds fjord in eastern North Greenland. Meddr Grønland 128:1-26

Lund S (1959a) The marine algae from East Greenland. I. Taxonomical Part. Meddr Grønland 156(1):1-247

Lund S (1959b) The marine algae from East Greenland. II. Geographic distribution. Meddr Grønland 156(2): $1-70$

Lüning K (1971) Seasonal growth of Laminaria hyperborea under recorded underwater light conditions near Helgoland. In: Crisp DJ (ed) Proc 4th European Mar Biol Symp. University Press, Cambridge, pp 347-361

Lüning K (1979) Growth strategies of three Laminaria species (Phaeophyceae) inhabiting different depth zones in the sublittoral region of Helgoland (North Sea). Mar Ecol Prog Ser 1:195-207

Lüning K (1980a) Control of algal-life-history by daylength and temperature. In: Price JH, Irvine DEG, Farnham WF (eds) The shore environment, vol 2. Ecosystems. Academic Press, New York, pp 915-945

Lüning K (1980b) Critical levels of light and temperature regulating the gametogenesis of three Laminaria species (Phaeophyceae). J Phycol 16:1-15

Lüning K (1988) Photoperiodic control of sorus formation in the brown alga Laminaria saccharina. Mar Ecol Prog Ser 45:137-144

Lüning K (1990) Seaweeds. Their environment, biogeography and ecophysiology. John Wiley, Sons, Inc., New York, Chichester, Brisbane, Toronto, Singapore, $527 \mathrm{pp}$

Lüning K (1991) Circannual growth rhythm in a brown alga, Pterygophora californica. Bot Acta 104:157-162

Lüning K, Dring MJ (1979) Continuous underwater light measurement near Helgoland (North Sea) and its significance for characteristic light limits in the sublittoral region. Helgol Meeresunters 32:403-424

Lüning K, Kadel P (1993) Daylength range for circannual rhythmicity in Pterygophora californica (Alariaceae, Phaeophyta) and synchronisation of seasonal growth by daylength cycles in several other brown algae. Phycologia 32:379-387

Lüning K, Neushul M (1978) Light and temperature demands for growth and reproduction of Laminarian gametophytes in southern and central California. Mar Biol 45:297-309

Lüning K, tom Dieck I (1989) Environmental triggers in algal Seasonality. Bot Mar 32:389-397

Lüning K, Schmitz K, Willenbrink J (1973) $\mathrm{CO}_{2}$ fixation and translocation in benthic marine algae. III. Rates and ecological significance of translocation in Laminaria hyperborea and L. saccharina. Mar Biol 23:275-281

McClintock JB, Karentz D (1997) Mycosporine-like amino acids in 38 species of subtidal marine organisms from McMurdo Sound. Antarctica. Ant Sci 9:392-398

McKamey KA, Amsler CD (2006) Effects of temperature and light on growth of the Antarctic algae Geminocarpus geminatus (Ectocarpales: Phaeophyceae) and Cladophora repens (Cladophorales: Cladophorophyceae) in culture. Phycologia 45:225-232

Miller AK, Pearse JS (1991) Ecological studies of seaweeds in McMurdo sound. Antarctica Am Zool 31:35-48

Moe RL, Silva PC (1977) Antarctic marine flora: uniquely devoid of kelps. Science 196:1206-1208

Moe RL, Silva PC (1981) Morphology and taxonomy of Himantothallus (including Phaeoglossum and Phyllogigas), an Antarctic member of the Desmarestiales (Phaeophyceae). J Phycol 17:15-29

Moe RL, Silva PC (1989) Desmarestia antarctica (Desmarestiales, Phaeophyceae), a new ligulate Antarctic species with an endophytic gametophyte. Plant Syst Evol 164:273-283

Moe RL, DeLaca TE (1976) Occurrence of macroscopic algae along the Antarctic Peninsula. Antarctic J 11:20-24

Moore PG, MacAlister HE, Taylor AC (1995) the environmental tolerances and behavioural ecology of the sub-Antarctic Beach-Hopper "Orchestia" scutigerula Dana (Crustacea: Amphipoda) from Husvik, South Georgia. J Exper Mar Biol Ecol 189:159-182

Neushul M (1965) Diving observations of subtidal Antarctic marine vegetation. Bot Mar 8:234-243

Neushul M (1972) Functional interpretation of benthic marine algal morphology. In: Abbott IS, Kurogi M (eds) Contributions to the systematic of benthic marine algae of the North Pacific. Japanese Society Phycology, Kobe, pp 47-71

Nishiguchi MK, Somero GN (1992) Temperature-and concentration-dependence of compatibility of the organic osmolyte $\beta$-dimethylsulfoniopropionate. Cryobiology 29:118-124

Novaczek I (1984) Response of gametophytes of Ecklonia radiata (Laminariales) to temperature in saturating light. Mar Biol 82:241-245

Novaczek I, Lubbers GW, Breeman AM (1990) Thermal ecotypes in amphi-Atlantic algae. I. Algae of Arctic to cold-temperate distribution (Chaetomorpha melagonium, Devaleraea ramentacea and Phycodrys rubens). Helgoländer Meeresunters 44:459-474

Orheim O, Allegrini I, Boissonnas J, Drewry D, Gascard JC, Hedberg D, Müller-Wille L, Prestrud P, Sors A, Tilzer M (1995) European research in the Arctic looking ahead. Norsk Polarinstitutt, Oslo 
Osmond CB (1994) What is photoinhibition? Some insights from comparisons of shade and sun plants. In: Baker NR, Bowyer NR (eds) Photoinhibition of photosynthesis, from the molecular mechanisms to the field. BIOS Scientific Publ., Oxford, pp 1-24

Papenfuss GF (1964) Catalogue and bibliography of Antarctic and Subantarctic benthic marine algae. Am Geophys Union, Antarctic Res Ser 1:1-76

Pedersen PM (1976) Marine, benthic algae from southernmost Greenland. Meddr Grønland 199(3):1-79

Peters AF (2003) Molecular identification, taxonomy and distribution of brown algal endophytes, with emphasis on species from Antarctica. In: Chapman ARO, Anderson RJ, Vreeland V, Davison IF (eds) Proceedings of the 17th international seaweed symposium. Oxford University Press, New York, pp 293-302

Peters AF, Breeman AM (1992) Temperature responses of disjunct temperate brown algae indicate long-distance dispersal of microthalli across the tropics. J Phycol 28:428-438

Peters AF, Breeman AM (1993) Temperature tolerance and latitudinal range of brown algae from temperate Pacific South America. Mar Biol 115:143-150

Peters AF, van Oppen MJH, Wiencke C, Stam WT, Olsen JL (1997) Phylogeny and historical ecology of the Desmarestiaceae (Phaeophyceae) support a Southern Hemisphere origin. J Phycol 33:294-309

Peters KJ, Amsler CD, Amsler MO, McClintock JB, Dunbar RB, Baker BJ (2005) A comparative analysis of the nutritional and elemental composition of macroalgae from the western Antarctic Peninsula. Phycologia 44:453-463

Polle A (1996) Mehler reaction: friend or foe in photosynthesis. Bot Acta 109:84-89

van de Poll WH, Eggert E, Buma AGJ, Breeman AM (2002) Temperature dependence of UV radiation effects in arctic and temperate isolates of three red macrophytes. Eur J Phycol 37:59-68

Quartino ML, Klöser H, Schloss IR, Wiencke C (2001): Biomass and associations of benthic marine macroalgae from the inner Potter Cove (King George Island, Antarctica) related to depth and Substrate. Polar Biol 24:349-355

Quartino ML, Zaixso HE, Boraso de Zaixso AL (2005) Biological and environmental characterization of marine macroalgal assemblages in Potter cove, South Shetland Islands, Antarctica. Bot Mar 48:187-197

Rakusa-Suszczewski S, Zieliński K (1993) Macrophytobenthos. In: Rakusa-Suszczewski S (ed) The Maritime Antarctic Coastal ecosystem of Admiralty Bay. Polish Academy of Sciences, Warsaw, pp 57-60

Ramus J (1978) Seaweed anatomy and photosynthetic performance: the ecological significance of light guides, heterogenous absorption and multiple scatter. J Phycol 14:352-362

Ramus J (1981) The capture and transduction of light energy. In: Lobban CS, Wynne MJ (eds) The biology of seaweeds. University of California Press, Berkeley, pp 458-492
Raven JA, Johnston AM (1991) Photosynthetic inorganic carbon assimilation by Prasiola stipitata (Prasiolales, Chlorophyta) under emersed and submersed conditions: relationship to the taxonomy of Prasiola. Br Phycol J 26:247-257

Raymond JA, Fritsen CH (2001) Semipurification and ice recrystallization inhibition activity of ice-active substances associated with Antarctic photosynthetic organisms. Cryobiology 43:63-70

Raymond JA, Knight CA (2003) Ice binding, recrystallization inhibition, and cryoprotective properties of iceactive substances associated with Antarctic sea ice diatoms. Cryobiology 46:174-181

Rhoades D (1979) Evolution of plant chemical defenses against herbivores. In: Rosenthal G, Janzed D (eds) Herbivores. Academic Press, New York, pp 4-54

Richardson M (1977) The ecology including physiological aspects of selected Antarctic marine invertebrates associated with inshore macrophytes. PhD Dissertation, University of Durham, pp 1-165 (plus references and appendix)

Richardson MG (1979) The distribution of the Antarctic marine macro-algae related to depth and substrate. $\mathrm{Br}$ Antarctic Bull 49:1-13

Roberts RD, Kühl M, Glud RN, Rysgard S (2002) Primary production of crustose coralline red algaein a high Arctic fjord. J Phycol 38:273-283

Rosenvinge LK (1898) Deuxième mémoire sur les algues marines du Groenland. Meddr Grønland 20:1-125

Salles S, Aguilera J, Figueroa FL (1996) Light field in algal canopies: changes in spectral light ratios and growth of Porphyra leucosticta. Thur. in Le Jol. Sci Mar 60:29-38

Schaffelke B, Lüning K (1994) A circannual rhythm controls seasonal growth in the kelp Laminaria hyperborea and L. digitata from Helgoland (North Sea). Eur J Phycol 29:49-56

Schmitz K (1981) Translocation. In: Lobban, CS, Wynne M J. (eds) The biology of seaweeds, Botanical monographs, vol 17. University of California Press, Berkeley, Los Angeles, pp 534-558

Schmitz K (1990) Algae. In: Behnke H-D, Sjolund RD (eds) Sieve elements. Comparative structure, induction and development. Springer Verlag, Berlin, Heidelberg New York, pp 1-18

Schoene T, Pohl M, Zakrajsek AF, Schenke HW (1998) Tide gauge measurements - a contribution for the long term monitoring of the sea level. Ber Polarforsch Meeresforsch 299:12-14

Schoenwaelder MEA (2002) The occurrence and cellular significance of physodes in brown algae. Phycologia 41:125-139

Schroeter B, Olech M, Kappen L, Heitland W (1995) Ecophysiological investigations of Usnea antarctica in the Maritime Antarctic. I. Annual microclimatic conditions and potential primary production. Antarct Sci 7:251-260

Schwarz A-M, Hawes I, Andrew N, Mercer S, Cummings V, Trush S (2005) Primary production potential of non-geniculate coralline algae at Cape Evans, Ross Sea, Antarctica. Mar Ecol Prog Ser 294:131-140 
Scrosati RA (1992) Estudio anatomico de Desmarestia ligulata de Argentina y D. menziesii de Antártida (Phaeophyceae). Physis A 113:89-98

Skottsberg CJF (1964) Antarctic phycology. In: Carrick R (ed) Comptes rendues premier symposium biologie Antarctique, Paris 1962. Hermann, Paris, pp 147-154

Slocum CJ (1980) Differential susceptibility to grazers in two phases of an intertidal alga: advantages of heteromorphic generations. J Exp Mar Biol Ecol 46: 99-110

Stockton W (1990) The intertidal zone at Palmer Station, Anvers Island, in the wake of the Bahia Paraiso spill. Antarctic J US 25:203

Svendsen P (1959) The algal vegetation of Spitsbergen. A survey of the marine algal flora of the outer part of Isfjorden. Norsk Polarinst Skrifter 116:1-49

Svendsen H, Beszczynska-Møller A, Hagen JO, Lefauconnier B, Tverberg V, Gerland S, Bischof K, Papucci C, Ørbæk JB, Zajaczkowski M, Azzolini R, Bruland O, Wiencke C, Winther JG, Dallmann W (2002) The physical environment of Kongsfjorden-Krossfjorden, an Arctic fjord system in Svalbard. Polar Res 21:133-166

Targett NM, Arnold TM (2001) Effects on secondary metabolites on digestion in marine herbivores. In: McClintock JB, Baker BJ (eds) Marine chemical ecology. CRC Press, Boca Raton, pp 391-412

Taylor WR (1966) Marine algae of the northeastern coast of North America. The University of Michigan Press, Ann Arbor

Thomas DN, Dieckmann GS (2002) Antarctic sea ice - a habitat for extremophiles. Science 295:641-644

Thomas DN, Wiencke C (1991) Photosynthesis, dark respiration and light independent carbon fixation of endemic Antarctic macroalgae. Polar Biol 11:329-337

Topcuoglu S., Fowler SW (1984) Factors affecting the biokinetics of Technetium $\left({ }^{95 \mathrm{~m}} \mathrm{Tc}\right)$ in marine macroalgae. Mar Environ Res 12:25-43

van Oppen MJH, Olsen JL, Stam W, van den Hoek C, Wiencke C (1993) Arctic-Antarctic disjunctions in the benthic seaweeds Acrosiphonia arcta (Chlorophyta) and Desmarestia viridis/willii (Phaeophyta) are of recent origin. Mar Biol 115:381-386

van Oppen MJH, Diekmann OE, Wiencke C, Stam WT, Olsen JL (1994) Tracking dispersal routes: phylogeography of Arctic-Antarctic disjunct seaweed Acrosiphonia arcta (Chlorophyta). J Phycol 30:67-80

Vinogradova KL (1995) The checklist of the marine algae from Spitsbergen. Bot J 80:50-61

Weslawski JM, Wiktor J, Zajaczkowski M, Swerpel S (1993) Intertidal zone of Svalbard. 1. Macroorganism distribution and biomass. Polar Biol 13:73-79

Weslawski JM, Zajaczkowski M, Wiktor J, Szymelfenig M (1997) Intertidal zone of Svalbard 3. Littoral of a subarctic, oceanic island: Bjornoya. Polar Biol $18: 45-52$

Wessels H, Hagen W, Molis M, Wiencke C, Karsten U (2006) Intra- and interspecific differences in palatability of Arctic macroalgae from Kongsfjorden (Spitzbergen) for two benthic sympatric invertebrates. J Exp Mar Biol Ecol 329:20-33
Westermeier B, Gomez I, Rivera PJ, Müller DG (1992) Antarctic marine macroalgae: distribution, abundance and necromass at King George Island, South Shetland. Antarctica. Ser Cient INACH 42:21-34

Weykam G, Wiencke C (1996) Seasonal photosynthetic performance of the endemic Antarctic alga Palmaria decipiens (Reinsch) Ricker. Polar Biol 16:357-361

Weykam G, Gómez I, Wiencke C, Iken K, Klöser H (1996) Photosynthetic characteristics and C:N ratios of macroalgae from King George Island (Antarctica). J Exp Mar Biol Ecol 204:1-22

Weykam G, Thomas DN, Wiencke C (1997) Growth and photosynthesis of the Antarctic red algae Palmaria decipiens (Palmariales) and Iridaea cordata (Gigartinales) during and following extended periods of darkness. Phycologia 36:395-405

Wiencke C (1988) Notes on the development of some benthic marine macroalgae of King George Island (Antarctica). Ser Cient INACH 37:23-47

Wiencke C (1990a) Seasonality of brown macroalgae from Antarctica - a long-term culture study under fluctuating Antarctic daylengths. Polar Biol 10:589-600

Wiencke C (1990b) Seasonality of red and green macroalgae from Antarctica - a long-term culture study under fluctuating Antarctic daylengths. Polar Biol 10:601-607

Wiencke C (2004) The coastal ecosystem of Kongsfjorden, Svalbard. Synopsis of biological research performed at the Koldewey Station in the years 1991-2003. Ber Polarforsch.Meeresforsch. 492:1-244

Wiencke C, Clayton MN (1990) Sexual reproduction, life history, and early development in culture of the Antarctic brown alga Himantothallus grandifolius (Desmarestiales, Phaeophyceae). Phycologia 29:9-18

Wiencke C, Clayton MN (2002) Antarctic seaweeds. Synopses of the Antarctic Benthos (Wägele JW, Sieg J (eds)), vol 9. Gantner, Ruggell

Wiencke C, Fischer G (1990) Growth and stable carbon isotope composition of cold-water macroalgae in relation to light and temperature. Mar Ecol Prog Ser 65:283-292

Wiencke C, tom Dieck I (1989) Temperature requirements for growth and temperature tolerance of macroalgae endemic to the Antarctic region. Mar Ecol Progr Ser 54:189-197

Wiencke C, tom Dieck I (1990) Temperature requirements for growth and survival of macroalgae from Antarctica and Southern Chile. Mar Ecol Prog Ser 59:157-170

Wiencke C, Stolpe U, Lehmann H (1991) Morphogenesis of the brown alga Desmarestia antarctica cultivated under seasonally fluctuating Antarctic daylengths. Ser Cient INACH 41:65-78

Wiencke C, Rahmel J, Karsten U, Weykam G, Kirst GO (1993) Photosynthesis of marine macroalgae from Antarctica: light and temperature requirements. Bot Acta 106:78-87

Wiencke C, Bartsch I, Bischoff B, Peters AF, Breeman AM (1994) Temperature requirements and biogeography of Antarctic, Arctic and amphiequatorial seaweeds. Bot Mar 37:247-259 
Wiencke C, Clayton MN, Schulz D (1995) Life history, reproductive morphology and development of the Antarctic brown alga Desmarestia menziesii J. Agardh. Bot Acta 108:201-208

Wiencke C, Clayton MN, Langreder C (1996) Life history and seasonal morphogenesis of the endemic Antarctic brown alga Desmarestia anceps Montagne. Bot Mar 39:435-444

Wiencke C, Vögele B, Kovaltchouk NA, Hop H (2004). Species composition and zonation of marine benthic macroalgae at Hansneset in Kongsfjorden, Svalbard. Ber Polarforsch Meeresforsch 492:55-62

Wilce RT (1963) Studies on benthic marine algae in northwest Greenland. Proc Int Seaweed Symp 4:280-287

Wilce RT (1990) Role of the Arctic Ocean as a bridge between the Atlantic and Pacific Oceans: fact and hypothesis. In: Garbary DJ, South GR (eds) Evolutionary biogeography of the marina algae of the North Atlantic. Springer-Verlag Berlin, Heidelberg, New York, London, Paris, Tokyo, Hong Kong, Barcelona, pp 323-348

Wilce RT (1994) The Arctic subtidal as habitat for macrophytes. In: Lobban CS, Harrison PJ (eds) Seaweed ecology and physiology. Cambridge University Press, Cambridge, pp 89-92
Winkler JB, Kappen L, Schulz F (2000) Snow and ice as an important ecological factor fort the cryptogams in the maritime Antarctic. In: Davison W, Howard-Williams C, Broady P (eds) Antarctic ecosystems: models for wider ecological understanding. New Zealand Natural Sciences, University of Canterbury, pp 220-224

Womersley HBS (1991) Biogeography of Australasian marine macroalgae. In: Clayton MN, King RJ (eds) Biology of marine plants. Longman Cheshire, Melbourne, pp 367-381

Zaneveld JS (1968) Benthic marine algae, Ross Island to Balleny Islands. Antarctic Map Folio Series. Am Geograph Soc NY, Folio 10:1-12

Zielinski K (1981) Benthic macroalgae of Admiralty Bay (King Goerge Island, Antarctica) and circulation of algal matter between the water and the shore. Pol Polar Res 2:71-94.

Zinova AD (1953) Brown algae of the northern seas of the U.S.S.R. Izdatel'Akademii Nauk SSSR, Moscow, Leningrad

Zinova AD (1955) Red algae of the northern seas of the U.S.S.R. Izdatel'Akademii Nauk SSSR, Moscow, Leningrad 